\title{
ANTI-SUIT INJUNGTIONS BETWEEN STATE AND FEDERAL COURTS
}

In the ordinary exercise of its equity powers, a state court may enjoin persons before it from proceeding in a court of another state. ${ }^{1}$ Similarly, a federal court may enjoin proceedings before another federal court. ${ }^{2}$ When both state and federal courts are involved, however, considerations based on the "independence" of the respective judicial systems have given rise to a general "hands off" policy with regard to injunctions by one court to bar proceedings before the other. ${ }^{3}$ The prohi-

1 E.g., Cole v. Cunningham, 135 U.S. 107 (1890); O'Haire v. Burns, 45 Colo. 432, 101 Pac. 755 (1909); Applestein v. United Board \& Carton Corp., 35 N.J. 343, 173 A.2d 225 (1961). It is clear that a state court has no power to issue an injunction directly restraining a foreign court. Sandage v. Studabaker Bros. Mfg. Co., 142 Ind. 148, 41 N.E. 380 (1895); Natalbany Lumber Co. v. McGraw, 188 La. 863, 178 So. 377 (1938). However, the court can act in personam as to persons over whom it has jurisdiction and who may be contemplating or prosecuting an inequitable suit in another state. Cole v. Cunningham, supra. As a general rule, this injunction will only be issued when both parties involved are residents of the state in which the enjoining court is located. This requirement is based upon the difficulty in enforcement where nonresidents are involved and upon the feeling that the home state of a party can best protect his rights. Thus, where both parties are non-residents courts will not enjoin. Marquis v. Marquis, 121 N.J. Eq. 288, 189 Atl. 388 (Ct. Err. \& App. 1936). Courts have enjoined proceedings when one party is a non-resident if there is some means of compelling his acquiescence or to prevent his taking inequitable advantage of the injunction. Doerr v. Warner, 247 Minn. 98, 76 N.W.2d 505 (1956). See Note, When Courts of Equity Will Enjoin Foreign Suits, 27 IowA L. Rev. 76, 77-79 (1941). All unqualified references to injunctions against "proceedings" in other courts herein can be presumed to have the meaning of injunctions against parties' proceeding in other courts.

2 National Equip. Rental, Ltd. v. Fowler, 287 F.2d 43 (2d Cir. 1961); Martin v. Graybar Elec. Co., 266 F.2d 202 (7th Cir. 1959); Food Fair Stores v. Square Deal Market Co., 187 F.2d 219 (D.C. Cir. 1951); Crosley Corp. v. Hazeltine Corp., 122 F.2d 925 (3d Cir. 1941), cert. denied, 315 U.S. 813 (1942). If only federal courts are involved, it appears that the grounds for an injunction to bar a suit may be much less stringent than those where state courts are involved. In the National Equip. Rental case, the only grounds discussed were those of concurrency of actions in two federal courts, and the court held that the prosecution of a subsequent suit between the same parties and on the same cause of action could be enjoined. These grounds are seldom, if ever, sufficient between state courts. See text accompanying notes 36-38 infra.

3 Cases denying federal injunctions against state proceedings include Amalgamated Clothing Workers v. Richman Bros. Co., 348 U.S. 511 (1955); Toucey v. New York Life Ins. Co., 314 U.S. 118 (1941); Kline v. Burke Constr. Co., 260 U.S. 226 (1922); Diggs \& Keith v. Wolcott, 8 U.S. (4 Cranch) 179 (1807). Cases denying state injunctions against federal proceedings include Donovan v. City of Dallas, 377 U.S. 408 (1964); Central Nat'I Bank v. Stevens, 169 U.S. 432 (1898); Moran v. Sturges, 154 U.S. 256 (1894); Riggs v. Johnson County, 73 U.S. (6 Wall.) 166 (1867); McKim v. Voorhies, 11 U.S. (7 Cranch) 278 (1812). 
bition against federal courts' enjoining state court proceedings has always been statutory ${ }^{4}$ and is presently embodied in section 2283 of the Judicial Code, ${ }^{5}$ while the state prohibition is the product of judicial decisions. ${ }^{6}$

Despite this mutual "hands off" policy, however, it is clear that under certain circumstances a federal court may enjoin proceedings before a state court. ${ }^{7}$ On the other hand, as a result of the recent Supreme Court decision in Donovan v. City of Dallas, ${ }^{8}$ it is also now clear that there has been no reciprocal relaxation of the state bar. In fact, Donovan sets forth this prohibition more absolutely and authoritatively than ever before.

It is the thesis of this comment that the Donovan decision has reinforced, if not indeed created, an unnecessary and undesirable "double standard" with regard to state and federal injunctive powers, and that as a general proposition state courts should be able to enjoin federal court proceedings whenever, in the converse situation, a federal court could enjoin proceedings before a state court.9 To develop this thesis, the comment will first set forth the equitable bases upon which a state court may enjoin proceedings before courts of another state, after which it will analyze the restrictions upon federal and state court power to enjoin proceedings before each other. It will be suggested that greater weight should be given these equitable standards, in determining whether to issue an anti-suit injunction between state and federal courts.

\section{Anti-Suit Injunctions Between State Courts}

An injunction to bar the prosecution of an out-of-state proceeding is a remedy issued with great caution by state courts. ${ }^{10}$ Such an in-

4 The statute was first enacted in 1793 (Act of March 2, 1793, ch. 22, § 5, I Stat. 334) and but for an exception as to proceedings in bankruptcy (REv. Srat. $\$ 720$ (I875)) remained unchanged until 1948.

528 U.S.C. \$ 2283 (1958).

6 See, e.g., Central Nat'l Bank v. Stevens, 169 U.S. 432 (1898); Riggs v. Johnson County, 73 U.S. (6 Wall.) 166 (1867); McKim v. Voorhies, Il U.S. (7 Cranch) 278 (1812).

7 See text accompanying notes 72-116 infra.

8377 U.S. 408 (1964).

9 This comment focuses on the criteria for and the desirability of injunctions between federal and state courts in actions in personam. Special areas such as those involving the Federal Employers Liability Act and state or federal criminal proceedings are beyond the scope of this examination. Also omitted is any detailed treatment of the situation where both proceedings are in rem. In such cases federal and state courts have long been able to enjoin proceedings before the other court when such proceedings threaten the jurisdiction of the court first taking custody of the res. See Princess Lida v. Thompson, 305 U.S. 456 (1939); Farmers' Loan \& Trust Co. v. Lake Street R.R., 177 U.S. 51 (1900); Freeman v. Howe, 65 U.S. (24 How.) 450 (1860).

10 A court must "exercise exceeding care with full realization of those acts of international courtesy between courts and their like desire to do equity between 
junction may well antagonize and offend the foreign court. Furthermore, it infringes on a party's right to bring suit on a transitory cause of action in any court in which jurisdiction over the defendant and the subject matter may be obtained. ${ }^{11}$ Thus, to justify the anti-suit injunction, there must be present equitable factors which go beyond the expense and inconvenience of having to defend a suit in a distant state.12 These factors must overcome the normal presumptions that the plaintiff is bringing the foreign suit in good faith and on a bona fide cause of action, and must serve to establish a danger of "immediate and irreparable harm" to the equity plaintiff.13 The primary advantage of the injunction, as compared with such other possible remedies as a refusal to appear and subsequent collateral attack, lies in its immediacy and greater assurance of success, together with its adaptability to meet the needs of the particular case.

If situations involving in rem jurisdiction are omitted, ${ }^{14}$ most of the cases employing injunctions seem to fall within one or more of the following four categories: (1) prevention of needless and repetitious relitigation; (2) protection of the equity plaintiff from fraud or collusion in the foreign suit; (3) prevention of attempts by the foreign suitor to evade or thwart local law by seeking to obtain a more favorable law elsewhere; and (4) prevention of multiple and duplicative actions, particularly when brought only to vex or harass.

\section{A. Relitigation}

When a case has been finally adjudicated by a state court, that court may enjoin a losing party from attempting to evade that judgment by re-opening the cause in a court of another state. ${ }^{15}$ For such an in-

litigants." Labak v. Graznar, 54 Ohio App. 191, 194, 6 N.E.2d 791, 792 (1935). See also Applestein v. United Board \& Carton Corp., 35 N.J. 343, 357, 173 A.2d 225, 232 (1961); Childress v. Johnson Motor Lines, Inc., 235 N.C. 522, 70 S.E.2d 558 (1952).

11 See Hughes v. Fetter, 341 U.S. 609 (1951); Illinois Life Ins. Co. v. Prentiss, 277 IIl. 383,115 N.E. 554 (1917).

12 See, e.g., Standard Oil Co. v. Reddick, 202 Ark. 393, 150 S.W.2d 612 (1941); Boston \& Me. R.R. v. Whitehead, 307 Mass. 106, 29 N.E.2d 916 (1940).

13 See, e.g., Oates v. Morningside College, 217 Iowa 1059, 252 N.W. 783 (1934); Wabash Ry. v. Peterson, 187 Iowa 1331, 175 N.W. 523 (1919). The prevention of "irreparable harm," of course, is the normal test required for any injunction and is not peculiar to the anti-suit injunction. See, e.g., Watkins v. Ruppert, 224 F.2d 47 (2d Cir. 1955).

14 See note 9 supra.

15 O'Haire v. Burns, 45 Colo. 432, 101 Pac. 755 (1909); Oates v. Morningside College, 217 Iowa 1059, 252 N.W. 783 (1934); Gordon v. Munn, 81 Kan. 537, 106 Pac. 286 (1910). Similarly, a state court should be able to enjoin a winning party from relitigating. the action on the grounds that he had already recovered full satisfaction and that the subsequent action was clearly brought to vex or harass. This situation is not one that often arises. 
junction to issue, it is necessary that there be an identity of issues and parties in both actions, ${ }^{16}$ and it will issue even though the judgment in the first suit would be res judicata in the second.17

Although the courts refer to upholding their own adjudicative powers in these cases, the basis of the injunction is primarily equitable. A showing of an intent to vex or harass or to obtain a new hearing on the same cause in a distant state indicates an absence of good faith or lack of a bona fide cause of action, and it has been held that to require the equity plaintiff to travel to the foreign state, if only to enter a plea of res judicata, constitutes undue hardship, for which an injunction is an appropriate remedy. ${ }^{18}$

The case of O'Haire $v$. Burns ${ }^{19}$ provides a good example. A suit involving Colorado mining claims was litigated in a Colorado court. The defendant prevailed. Thereafter, obtaining personal jurisdiction over the defendant while he was temporarily in Iowa, the defeated plaintiff attempted to relitigate the same cause in an Iowa court. The defendant obtained an injunction from the Colorado court barring the plaintiff in the Iowa action from prosecuting that suit. The Supreme Court of Colorado affirmed the issuance of the injunction, stating:

The decree in this case does not attempt to enjoin or control the Iowa court in any manner, and is not a refusal to give that full faith and credit to its judicial proceedings as contemplated by the Constitution of the United States, but is simply a decree restraining one of our own citizens from attempting to do that which is wrong, unlawful, against good conscience, stating when, and providing a method whereby there is, can, and should be, an end to litigation between citizens of our own state as to matters accruing therein. ${ }^{20}$

16 Cf. Southern Calif. Petroleum Corp. v. Harper, 273 F.2d 715 (5th Cir. 1960).

17 A plea of res judicata requires an appearance in the foreign suit, causing harm in the form of unnecessary expense, inconvenience in travel, and loss of time. Furthermore, a plea of res judicata is much less certain than an injunction-it may not be timely or otherwise may not succeed. The enjoining court, having previously adjudicated the case on the merits, would seem in most cases to be in a better position to determine the extent and nature of duplication. Cases involving problems created by reliance on res judicata in this context include Treinies v. Sunshine Mining Co., 308 U.S. 66 (1939) and Barr v. Thompson, 350 S.W.2d 36 (Tex. Civ. App. 1961). In Phoenix Fin. Co. v. Iowa-Wisconsin Bridge Co., 115 F.2d 1 (8th Cir. 1940), one of the cases involved in Toucey v. New York Life Ins. Co., 314 U.S. 118 (1941), a plaintiff who had irrevocably lost in the federal court thereafter instituted five separate suits on the same cause in state courts in Delaware. In one of the five the plea of res judicata failed, although the facts were substantially the same in all the suits. See 1 A Moore, Federal. Practice 70.208 [2], at 2311 (2d ed. 1961).

18 See, e.g., Oates v. Morningside College, 217 Iowa 1059, 1066, 252 N.W. 783, 786-87 (1934).

1945 Colo. 432, 101 Pac. 755 (1909).

20 Id. at 441, 101 Pac. at 757. 
Even though the first judgment could be pleaded in bar in the Iowa suit, the court stated that to require the defendant in that suit to travel five hundred miles to a foreign jurisdiction, when all the parties, witnesses and the property in question were native to Colorado, would be indefensible. The court also expressed the fear that if the injunction had been denied, the defeated plaintiff could have continued to sue on the same cause of action in any jurisdiction in which personal jurisdiction over the defendant might have been obtained.

The anti-suit injunction to prevent relitigation, as used in O'Haire, seems a necessary and desirable means to prevent inequity. When properly based, its advantages outweigh whatever interference and friction it may cause.

\section{B. Fraud or Collusion}

State courts may enjoin parties to out-of-state suits where such suits were part of a general scheme to defraud the equity plaintiff ${ }^{21}$ or where jurisdiction over him was obtained through fraud. ${ }^{22}$ Determinative here is the desire of the enjoining court to prevent fraud or collusion and to protect persons within its jurisdiction from being called many miles at considerable expense to defend fraudulent actions. ${ }^{23}$ In Reed $v$. Hollingsworth, ${ }^{24}$ for example, the directors of a Colorado corporation had acted in collusion with the vendor of land to the corporation to permit a forfeiture of the land. Thereafter, the directors, residents of Iowa, repurchased the land individually at a greatly reduced price and brought an action in Colorado to quiet title against the corporation. The Supreme Court of Iowa, in connection with a general derivative suit, held that the Iowa shareholders could obtain an injunction to bar the prosecution of the Colorado suit. The use of the injunction in such cases seems proper.

Similarly, since judgments obtained through fraud or collusion are

21 Cole v. Cunningham, 133 U.S. 107 (1890); Reed v. Hollingsworth, 157 Iowa 94, 135 N.W. 37 (1912); Child v. Henry, 183 Minn. 170, 236 N.W. 202 (1931).

22 Greer v. Cook, 88 Ark. 93, 113 S.W. 1009 (1908); Usen v. Usen, 136 Me. 480, 13 A.2d 738 (1940); Cameron \& Co. v. Abbott, 258 S.W. 562 (Tex. Civ. App. 1924). In Morad v. Williams, 177 Misc. 933, 32 N.Y.S.2d 463 (Sup. Ct. 1942), a New York court enjoined a New York resident from suing another New York resident in Florida for alienation of the affections of the equity defendant's wife, such actions being valid in Florida but contrary to the public policy of New York. In part, the New York court based its injunction on the ground that the equity plaintiff had been induced by the defendant to come with him to Florida to recuperate from illness and that he was promptly served with process on arrival.

23 The showing of fraud in the foreign suit vitiates the normal presumption that that action was brought in good faith and on a bona fide cause, and thus supports the conclusion that to compel a resident to defend such actions constitutes undue hardship. See text accompanying notes 12.13 supra.

24147 Iowa 94, 135 N.W. 37 (1912). 
considered void, ${ }^{25}$ their enforcement has been enjoined. ${ }^{26}$ Even in such cases, however, courts have limited the use of injunctions to situations where there is a showing that the winning party is actively enforcing the fraudulent judgment to the immediate and irreparable harm of the defendant and that the courts where such enforcement is sought are unable or unwilling to act.27 In some cases courts have enjoined the use of fraudulent documents or other limited aspects of a foreign suit, ${ }^{28}$ but since the parties are already before the foreign court and the facts of such fraud can be revealed to it, considerations of comity and logic would seem to weigh against such injunctions.

\section{Public Policy}

When a party sues in a foreign court in order to evade local laws, whether procedural ${ }^{29}$ or substantive, ${ }^{30}$ courts have frequently enjoined the institution or prosecution of the suit. Before issuing the injunction,

25 See Weimar v. Weimar, 25 N.Y.S.2d 343 (Sup. Ct. 1940); cf. Wells Fargo \& Co. v. Taylor, 254 U.S. 175 (1920); Simon v. Southern Ry., 236 U.S. 115 (1915).

26 E.g., Engel v. Scheuerman, 40 Ga. 207 (1869). A distinction, perhaps not wholly viable, has been drawn in these cases between extrinsic and intrinsic fraud. Generally, extrinsic fraud is fraud involved in the obtaining of a judgment concerning a transaction, while intrinsic fraud goes to the transaction itself. The general feeling is that the adjudicating court can best rule as to intrinsic fraud and objections are waived once judgment is entered, while extrinsic fraud renders the judgment void and open to collateral or direct attack, including an injunction to bar its enforcement. See 7 Moore, Federal Practice 19 60.24, 60.36, 60.37, at 245-57, 601-35 (2d ed. 1955); Note, 48 Iowa L. Rev. 398 (1963).

27 Normally, appeal in the court where the judgment was rendered is the proper remedy in this situation. However, fraudulent judgments often go by default, and enforcement may be sought either in the defendant's home state or in other states where he is vulnerable. In such cases factors such as distance, expense and the fact that appeal is no longer available in the forum state are relevant to the issuance of an injunction. In Second Nat'l Bank v. Thompson, 141 N.J. Eq. 188, 56 A.2d 492 (1947), the New Jersey court enjoined enforcement of a New Jersey judgment which the victorious party in a Pennsylvania suit had obtained by pleading that judgment, obtained through fraudulent use of the default process. However, as there was no showing of immediate harm since the victorious party was not actively attempting to enforce the Pennsylvania judgment, the court refused to enjoin there, noting that "the Chancery Courts of Pennsylvania are also courts of conscience and there is no showing that defense cannot be there made and adequately passed upon." Id. at 202, $56 \mathrm{~A} .2 \mathrm{~d}$ at 501.

28 Child v. Henry, 183 Minn. 170, 236 N.W. 202 (1931) ("wilfully false, sham, and fraudulent" counterclaim); cf. Twaits v. Pennsylvania R.R., 77 N.J. Eq. 103, 73 Atl. 1010 (1910) (fraudulently obtained release).

29 Pere Marquette Ry. v. Slutz, 268 Mich. 388, 256 N.W. 458 (1934); New York, C. \& St. L.R.R. v. Matzinger, 136 Ohio St. 271, 25 N.E.2d 349 (1940).

30 Sandage v. Studabaker Bros. Mfg. Co., 142 Ind. 148, 41 N.E. 380 (1895); Keyser v. Rice, 47 Md. 203 (1877); Dehon v. Foster, 86 Mass. (4 Allen) 545 (1862). A difference only as to procedure or rules of evidence has generally been held not to warrant the issuance of an injunction. See Standard Oil Co. v. Reddick, 202 Ark. 393, 150 S.W.2d 612 (1941); Delaware, L. \& W.R.R. v. Ashelman, 300 Pa. 291, 150 AtI. 475 (1930). 
the local court must determine from the facts of the situation that its own law will not be applied and that this will unduly prejudice the rights of the defendant. ${ }^{31}$ In Weaver v. Alabama Great So. R.R., ${ }^{32}$ for example, an injunction was granted restraining an Alabama resident from suing an Alabama corporation in a Georgia court on a collision occurring in Alabama. The plaintiff had chosen the Georgia jurisdiction because Alabama decisions had established as a rule of law that a driver who failed to stop, look and listen for a train was guilty of contributory negligence, while in Georgia it was clear that such evidence would merely go to the jury together with all other evidence. In issuing the injunction, the Alabama Supreme Court stated that "it is clear that, by resorting to the Georgia court for the enforcement of his alleged claim against complainant, respondent seeks an adjudication thereof under a theory of the law which denies to complainant the benefit of a perfect legal defense which would be available to him in Alabama courts, a result which is offensive to justice and equity." 33

In cases where the foreign suit appears otherwise to have been brought in good faith and the only alleged basis for the injunction is that the substantive law of the foreign state differs from that of the local state, the injunction ordinarily will not issue, since it is assumed that the forum court will apply the appropriate law to the case..$^{34}$ Nevertheless, equitable factors such as the motive of the plaintiff, trial expenses, unavailability of witnesses, and time and distance have been deemed sufficient to justify the issuance of the injunction in some of these cases. ${ }^{35}$

31 Weaver v. Alabama Great So. R.R., 200 Ala. 432, 76 So. 364 (1917); Natalbany Lumber Co. v. McGraw, 188 La. 863, 178 So. 377 (1938); Sharp v. Learned, 185 Miss. 872,188 So. 302 (1939). This is not an easy determination. Under traditional choiceof-law rules a court will apply the law of the place of the making of the contract or of the place where the tort occurred. Modern courts, however, have modified this in terms of "interest analysis" and "significant contacts." In general, where a court is uncertain as to what law the adjudicating court will apply, and in the absence of other strong equitable grounds, no injunction should issue. See Royal League v. Kavanagh, 233 Ill. 175, 84 N.E. 178 (1908). In connection with "interest analysis," see generally B. Currie, Married Women's Contracts: A Study of Confict-of-Laws Method, 25 U. CHI. L. REv. 227 (1958).

32200 Ala. 432,76 So. 364 (1917).

33 Id. at 435,76 So. at 367 .

34 Bank Sav. Life Ins. Co. v. Wood, 122 Kan. 831, 253 Pac. 431 (1927); Bigelow v. Old Dominion Mining \& Smelting Co., 74 N.J. Eq. 457, 71 Atl. 153 (Ch. 1908); Buchanan-Vaughan Auto Co. v. Woosley, 218 S.W. 554 (Tex. Civ. App. 1919). In the case of procedural law, under standard choice-of-law rules, the law of the forum is appropriate. However, when this will result in depriving a defendant of rights available to him if the suit had been brought in an "interested" state, courts of that state may have a basis for an injunction, as in the Weaver case. See B. Currie, supra note 31 .

35 See Sandage v. Studabaker Bros. Mfg. Co., 142 Ind. 148, 41 N.E. 380 (1895); Dehon v. Foster, 86 Mass. (4 Allen) 545 (1862); Dinsmore v. Neresheimer, 32 Hun. 204 (N.Y. Sup. Ct. 1884). 
The injunction on the grounds of public policy in cases such as Weaver should depend on the proof of an intent to evade local law, without justifiable reasons for bringing a suit in the foreign state. Moreover, for reasons of comity such an injunction should seldom, if ever, be issued where the foreign state has contacts with the suit, other than serving as forum, and thus reasonable grounds exist for the application of its law.

\section{Multiplicity of Actions and Concurrency}

State courts generally will not enjoin parties within their jurisdiction from prosecuting suits in more than one jurisdiction simultaneously. ${ }^{36}$ Similarly, as a general rule, a state court will not enjoin a defendant in an action before it from instituting his own suit on the same cause in a second jurisdiction. ${ }^{37}$ This reluctance to enjoin is based on the theory that each court is competent to hear the cause and that with a transitory cause of action a party acting in good faith has "the legal right to bring his action in any court which has jurisdiction of the subject matter and which can obtain jurisdiction of the parties." 38

Nevertheless, state courts having prior jurisdiction over the controversy have enjoined the prosecution of subsequent suits involving the same parties and cause of action. Certainly, in accord with the preceding analysis, an injunction should be available to prevent concurrent actions brought only to evade local law. More generally, however, anti-suit injunctions have been issued on a showing that the subsequent suits were motivated only by a desire to vex and harass, and thus were not brought in good faith. ${ }^{39}$ However, state courts have also

36 E.g., Illinois Life Ins. Co. v. Prentiss, 277 Ill. 383, 115 N.E. 554 (1917); Miller v. Myers, 75 Misc. 297, 135 N.Y. Supp. 73 (Sup. Ct.), aff'd without opinion, I5I App. Div. 438,135 N.Y. Supp. 1128 (1912). On the other hand, as between two federal courts, the mere fact of concurrent actions involving the same parties and the same issues has been held sufficient to give rise to an injunction against the second proceeding. National Equip. Rental, Ltd. v. Fowler, 287 F.2d 43 (2d Cir. 1961).

37 This constitutes what has been termed "reactive" litigation, as opposed to multiple suits brought by the same party, which is "repetitive" litigation. See Vestal, Reactive Litigation, 47 Iowa L. REv. I1 (1961); Vestal, Repetitive Litigation, 45 Iowa L. REv. 525 (1960).

38 Mllinois Life Ins. Co. v. Prentiss, 277 Ill. 383, 387, 115 N.E. 554, 556 (1917). In addition to these general considerations there are situations where the second action is clearly justified and duplication inevitable. An example may be where a creditor has obtained security through attachment in the second jurisdiction which he did not have in the first. See generally Vestal, Reactive Litigation, 47 IowA L. Rev. 11, 24 (1961); Note, 60 Colum. L. REv. 684, 698-709 (1960).

39 See Williams v. Payne, 150 Kan. 492, 94 P.2d 341 (1939); Locomobile Co. v. American Bridge Co., 80 App. Div. 44, 80 N.Y. Supp. 288 (1908). State courts disagree as to what constitutes vexatious litigation. While this is primarily a matter of motive, it has been held inferable from objective facts, such as the number of suits brought, lack of any gain or benefit to the plaintiff from the suit and the distance of the forum from 
enjoined to prevent unnecessary and wasteful duplication, or because the foreign suit will unduly prejudice the progress of the local action, or because that suit may subvert the jurisdiction of the local court, or because all relevant contacts are with the local state, leading to the conclusion that the action can best be adjudicated there. ${ }^{40}$ Typical of such holdings is Childress $v$. Johnson Motor Lines, Inc., ${ }^{41}$ where a North Carolina court enjoined the defendant in an action before it from instituting a suit on the same collision in a Virginia court. The accident had occurred in Virginia, but both the plaintiff and defendant were from North Carolina. The Supreme Court of North Carolina, in approving the issuance of the injunction, recited the general rule against injunctions but went on to say that "an action or proceeding in another state ordinarily may be enjoined where it is made to appear that its prosecution will interfere unduly and inequitably with the progress

the place of residence of both parties. See O'Loughlin v. O'Loughlin, 6 N.J. 170, 78 A.2d 64 (1951); Labak v. Graznar, 54 Ohio App. 191, 6 N.E.2d 790 (1935); cf. University of Texas v. Morris, 162 Tex. 60, 344 S.W.2d 427, cert. denied, 366 U.S. 973 (1961). In the O'Loughlin and Labak cases there was no action on the merits pending before the court at the time of the issuance of the injunction. On the other hand, the Connecticut Supreme Court of Errors in Bridgeport Hydraulic Co. v. Pearson, 139 Conn. 186, 91 A.2d 778 (1952), where a party had brought several suits in different Connecticut courts to block the taking of property under completed eminent domain proceedings, reviewed an injunction issued on the grounds of vexatiousness and relitigation. The court affirmed to prevent relitigation, but stated: "It is well settled that equity may enjoin vexatious litigation. [Citing cases.] This power of equity exists independently of its power to prevent a multiplicity of actions. It is based on the fact that it is inequitable for a litigant to harass an opponent, not for the attainment of justice, but out of malice. 28 AMr. JUR. 249, §52. To be vexatious, litigation must be prosecuted not only without probable cause but also with malice." Id. at 194, 91 A.2d at 781 . The court found no actual threats or vilification which would justify an inference of malice in the facts of the case before it. Where there are a large number of concurrent suits an old equity device called the "bill of peace" may be applicable. This remedy usually consists of consolidating all of the suits into one action, but also may involve injunctions to ensure that the court of equity will be able to proceed without interference with the rights of any of the parties. See Lyons v. Importers' \&: Traders' Nat'l Bank, $214 \mathrm{~Pa} .428$, 63 Atl. 827 (1906); IA MOORE, Federal Practice If 0.227, at 2626-27 (2d ed. 1961).

40 E.g., Doerr v. Warner, 247 Minn. 98, 76 N.W.2d 505 (1956); Applestein v. United Board \& Carton Corp., 35 N.J. 343, 173 A.2d 225 (1961); Barr v. Thompson, 350 S.W.2d 36 (Tex. Civ. App. 1961). In Barr v. Thompson a Texas court temporarily enjoined the prosecution of a stockholders' derivative suit in Delaware on the bill of the directors and of certain partners in an affiliated firm. The Delaware suit was first in time, the corporation had been formed under Delaware law, and the subsequent Texas proceeding sought only a declaratory judgment. Although such elements of convenience as access to information, witnesses and availability of parties were in favor of the Texas proceeding, the court did not rest on a forum non conveniens approach, noting that this doctrine had never been recognized in Texas. Rather, the court stressed the interest of equity in preventing multiple and inconclusive actions, emphasizing that all parties and issues were before the Texas court, whereas all parties and issues were not before the Delaware court. 350 S.W.2d at 42.

41235 N.C. 522, 70 S.E.2d 558 (1952). 
of local litigation or with the establishment of rights properly justiciable in the local court; or that it is unduly annoying, vexatious, and harassing to the complainant, and reasonably calculated to subject him to oppression or irreparable injury." 42

The Childress result may be justifiable in that it reduces the wasteful litigation resulting from duplicative suits and prevents the possible ill effects of a race to judgment in each suit. However, in view of such alternative remedies available as the stay, compulsory counter-claim, forum non conveniens, and consolidation, this result seems unwarranted. And although there are alternative remedies available in the relitigation, fraud and public policy areas, there are also present in those cases objective factors, not found in concurrency cases, to vitiate any presumption of good faith and a bona fide cause of action. While the purpose of multiple and repetitive concurrent suits may be equally to vex or harass, this is much more difficult to prove. Where a purely vexatious motive cannot be conclusively shown, such multiplicity should be tolerated, not only on grounds of comity but also because there are often valid reasons for multiple actions. ${ }^{43}$ On the other hand, where the motive of vexatiousness can be clearly established, there is no reason to impose a stricter standard in the concurrency area. In such cases, it seems undesirable to force the equity plaintiff to incur unnecessary expense and inconvenience, as well as a possible adverse result, and an injunction should be an available remedy. ${ }^{44}$

\section{The Federal Court Prohibition}

\section{A. Development and Interpretation}

The Congress in 1793 made it clear how it felt about the power of federal courts to enjoin proceedings before state courts: " $[\mathrm{N}] \mathrm{o}$. . . writ of injunction [shall] be granted to stay proceedings in any court of a state ...."45 Two apparent primary motives for this statute were to prevent unhampered intrusions by the new federal courts into the then well-established state court domain and to codify the then prevailing prejudices against any extension of equity jurisdiction and power.46

42 Id. at 531,70 S.E.2d at 565 .

43 See note 38 supra.

44 Cf. University of Texas v. Morris, 162 Tex. 60, 344 S.W.2d 427, cert. denied, 366 U.S. 973 (1961).

45 Act of March 2, 1793. Ch. $22, \S 5,1$ Stat. 335 , now embodied in 28 U.S.C. $\S 2283$ (1958).

46 Primary source material dealing with the Act of 1793 is scarce and inconclusive. The most useful sources available are the reports of Attorney General Edmund Randolph to Congress on the proposed bill's changes in the Judiciary Act of 1789, AM. STATE PAPERS, 1 Misc. No. 17, at 21-36 (1834), and the biography of Oliver Ellsworth, 
While changes in American political structure and focus over the past 150 years have practically eliminated these narrow reasons for the prohibition, the need for independent federal and state court systems and a fear of the dangerous friction generated by the free use of the injunction remain. 47

Despite the absolute language of the statute, however, federal courts approved the use of the anti-suit injunction to bar the prosecution of state court suits in a number of situations. ${ }^{48}$ Beginning with French $v$. Hay ${ }^{49}$ in 1875 , exceptions were judicially created to allow federal injunctions to bar state officials from enforcing unconstitutional statutes or ordinances, ${ }^{50}$ to prevent parties from relitigating in state courts controversies and issues previously adjudicated by a federal court, ${ }^{51}$ to prevent the enforcement of state court judgments obtained through fraud, ${ }^{52}$ and to keep state courts from acting in cases previously removed to a federal court..53

In 1941, however, in Toucey v. New York Life Ins. Co.,54 the Supreme Court expressly struck down the "relitigation" exception, and advocated, in an opinion by Mr. Justice Frankfurter, a strict interpretation of the

then an important member of the Senate committee considering the bill. See Brown, LIFE OF OlIVER ElLsworth 194 n.16, 209 (1905). Another possible explanation of the statute, but one generally dismissed by commentators, is that the anti-injunction provisions were a reaction to Chisholm v. Georgia, 2 U.S. (2 Dall.) 419 (1793), which extended federal jurisdiction at the expense of the states and generated the eleventh amendment. See generally Toucey v. New York Life Ins. Co., 314 U.S. 118, 129-32 (1941) (Frankfurter, J.); Taylor \& Willis, The Power of Federal Courts to Enjoin Proceedings in State Courts, 42 YALE L.J. 1169, $1170-72$ (1933); Warren, Federal and State Court Interference, 43 HARv. L. REv. 345, 347-50 (1930).

47 See Leiter Minerals, Inc. v. United States, 352 U.S. 220, 225-26 (1957); Toucey v. New York Life Ins. Co., 314 U.S. 118, 129-30 (1941).

48 See generally Durfee \& Sloss, Federal Injunction Against Proceedings in State Courts: The Life History of a Statute, 30 Mrck. L. REv. 1145, 1149-69 (1932); Taylor \& Willis, supra note 46, at 1172-97; Warren, supra note 46, at 366-78; Note, 74 HaRv. L. Rev. 726, 727-32 (1961); Comment, 35 Calif. L. Rev. 545, 546-53 (1947); Comment, 13 So. Cal. L. Rev. 331, 332-39 (1940).

4989 U.S. (22 Wall.) 250 (1875). Prior to this the courts had generally ignored the statute, denying injunctions against state court proceedings on grounds of comity or "necessity." See Peck v. Jenness, 48 U.S. (7 How.) 612 (1849). See generally Warren, supra note 46 , at 348,359 .

50 E.g., Truax v. Raich, 239 U.S. 33 (1915); Ex parte Young, 209 U.S. 123 (1908).

51 Supreme Tribe of Ben-Hur v. Cauble, 255 U.S. 356 (1921); Julian v. Central Trust Co., 193 U.S. 93 (1904); cf. Local Loan Co. v. Hunt, 292 U.S. 234 (1934).

52 Wells Fargo \& Co. v. Taylor, 254 U.S. 175 (1920); Simon v. Southern Ry., 236 U.S. 115 (1915); cf. Marshall v. Holmes, 141 U.S. 589 (1891).

53 E.g., Madisonville Traction Co. v. Saint Bernard Mining Co., 196 U.S. 239 (1905); Dietzsch v. Huidekoper, 103 U.S. 494 (1881); French v. Hay, 89 U.S. (22 Wall.) 250 (1875).

54314 U.S. 118 (1941). 
statutory prohibition. The Court was motivated by a desire to give effect to congressional pronouncements in the delicate matter of distributing judicial power between federal and state courts.

But Congress apparently no longer desired an absolute prohibition. In 1948 the statute was changed significantly, and the Toucey holding expressly rejected. Section 2283 now reads:

A court of the United States may not grant an injunction to stay proceedings in a State court except as expressly authorized by Act of Congress, or where necessary in aid of its jurisdiction, or to protect or effectuate its judgments. ${ }^{55}$

This revision has not resolved the problems of interpretation, but rather seems to have generated new confusion. The Reviser's Note to section 2283 indicates that the three phrases added to the general prohibition were intended specifically to restore the "Act of Congress," "removal," and "relitigation" exceptions, but the Note goes on broadly to state that "the revised section restores the basic law as generally understood and interpreted prior to the Toucey decision." 56 Since there were preToucey exceptions that do not seem to come within the language of the revised section, and since the law prior to Toucey was by no means well-defined and consistently applied, the scope of the present federal injunctive power is not nearly as clear as the revisers seem to have expected. 57

The two primary interpretations advanced to explain section 2283 may be characterized as a strict and a flexible reading of the statutory language. While both views recognize that the prohibition is based on comity and that federal jurisdiction has not been wholly preempted, ${ }^{58}$ the positions differ in interpreting both the scope and bases of the exceptions.

Mr. Justice Frankfurter was a leading spokesman for the strict interpretation. In Amalgamated Clothing Workers v. Richman Bros. Co.,59 one of the most recent Supreme Court cases on section 2283, he stated: "This is not a statute conveying a broad general policy for appropriate ad hoc application. Legislative policy is here expressed in a clear-cut

65 June 25, 1948, ch. 646, 62 Stat. 968 (1948), 28 U.S.C. § 2283 (1958).

56 H.R. REP. No. 308, 80th Cong., Ist Sess. Al81 (1948).

57 See generally Kochery, Conflict of Jurisdiction: 28 U.S.C. \$ 2283 and Exclusive Federal Jurisdiction, 4 Buffalo L. Rev. 269 (1955); Comment, 35 CalIF. L. Rev. 545, $562-63$ (1947).

58 See, e.g., Hale v. Bimco Trading, Inc., 306 U.S. 375, 378 (1939); Wells Fargo \& Co. v. Taylor, 254 U.S. 175, 183 (1920); Baines v. City of Danville, 337 F.2d 579, 593 (4th Cir. 1964).

59348 U.S. 511 (1955). 
prohibition qualified only by specifically defined exceptions." 60 The exceptions envisaged by this view include only those specifically set forth in the Reviser's Note-Act of Congress, removal, and relitigationand, as these have been applied by the federal courts, are based wholly upon considerations of federal policy, divorced from any examination into the equities of the particular case.61 Thus, the application of the anti-suit injunction depends upon the factual situation falling into one of these three areas, which themselves have been further narrowly defined. ${ }^{62}$

In part, the strict reading views section 2283 as an attempt to severely limit and control the use of the anti-suit injunction by federal courts in all future cases. ${ }^{63}$ This view has been sharply criticized on an historical, as well as a practical, level. ${ }^{64}$ Moreover it seems just as reasonable to interpret the revision as intending to restore the judicial flexibility existing before and endangered by the Toucey decision. ${ }^{65}$ Certainly the language of the three statutory exceptions is not overly restrictive, and could well be read to allow injunctions in situations other than those described in the Reviser's Note. Furthermore, it can be argued that since judicial exceptions to the virtually absolute statutory language were created on equitable as well as policy grounds prior to Toucey, this same potential exists today, particularly since the revision apparently intends to restore the whole law as it existed prior to Toucey.

A flexible reading of section 2283 is suggested by the Fourth Circuit in the recent case of Baines $v$. City of Danville. ${ }^{66}$ Although the court did not find express authorization in the Civil Rights Act of 1957 for a federal injunction to bar the prosecution in state courts of Negro demonstrators for violation of local ordinances and injunctions, and thus refused to enjoin, the court did address itself to the general policy of section 2283 and remanded the case for consideration of possible

60 Id. at 515-16.

61 See, e.g., Bowles v. Willingham, 321 U.S. 503 (1944) (Act of Congress); Allied Mut. Ins. Co. v. Roberson, 306 F.2d 130 (4th Cir. 1962) (relitigation).

62 See, e.g., Joseph L. Muscarelle, Inc. v. Central Iron Mfg. Co., 328 F.2d 791 (3d Cir. 1964); Loyd v. Stewart \& Nuss, Inc., 327 F.2d 642 (9th Cir. 1964); Commerce Oil Ref. Co. v. Miner, 303 F.2d 125 (1st Cir. 1962). In a number of lower federal court cases a general "twilight" doctrine has been formulated to deny the issuance of an injunction in all borderline situations. See T. Smith \& Son, Inc. v. Williams, 275 F.2d 397 (5th Cir. 1960), and cases cited therein.

63 See Amalgamated Clothing Workers v. Richman Bros. Co., 348 U.S. 511, 514 (1955).

$64 \mathrm{Id}$. at 522-23 (Warren, C.J., dissenting); Kochery, supra note 57, at 275-86.

65 See 1A Moore, Federal Practice |f 0.219, at 2601 (2d ed. 1961); 7 Moore, Federal. Practice If 60.40, at 648 (2d ed. 1955); Comment, 35 Conn. B.J. 378, 386 (1961).

60337 F.2d 579 (4th Cir. 1964). 
injunctions to bar future prosecutions under these ordinances. ${ }^{67}$ In the opinion by Judge Haynsworth, the court noted that since section 2283 had been "fathered by the principles of comity," it "should be read in the light of those principles and, though absolute in its terms, is inapplicable in extraordinary cases in which an injunction against state court proceedings is the only means of avoiding grave and irreparable injury." 68

This view would appear to be too "flexible." An unwarranted fourth exception, one whose only bounds are the broad requirements of equity, is engrafted onto a "clear legislative mandate." 69 While there may be precedent for additional exceptions to those specifically enumerated, arising where urgent policy considerations are found, such as where the United States seeks the injunction, ${ }^{70}$ the equity exception suggested in Baines lacks the inherent limitations of the exception for the United States and invites federal courts to ignore the prohibition at will. Thus, the interaction of federal and state courts would be thrown upon virtually the same informal doctrines of comity that govern state court relations. ${ }^{71}$ This result cannot be justified where Congress, acting in what it deems to be the national interest, has seen fit to impose a much stricter standard.

On the other hand, equity cannot be dismissed in considering the application and policies of section 2283. The basis and effectiveness of the anti-suit injunction rests upon its adaptability and responsiveness to the needs of each specific case. The automatic application suggested under the "strict" interpretation creates a new policy which ignores unconscionable harm or the availability and effectiveness of other remedies, and which cannot be attributed to the purposes of section 2283. The fact that the revisers considered certain specific situations does not mean that they ignored the foundations for these exceptions, and certainly does not mean that these foundations were to be dis-

67 The court also found equitable bases for a temporary injunction in the denial of bail, transference of trial by the state court to a location two hundred miles from the defendants' homes, and its desire to preserve the justiciability of the case pending the time for a full hearing. $I d$. at 593-94.

$68 \mathrm{Id}$. at 593.

69 The court in Baines based its interpretation on Douglas v. City of Jeannette, 319 U.S. 157 (1943), which only implied that an injunction might be issued to bar threatened state prosecutions based on an unconstitutional statute upon a "showing of danger of irreparable injury, 'both great and immediate." 319 U.S. at 164. In no sense can this case be said to create a general equity exception. See Note, 50 VA. L. REv. 1404, 1424-26 (1964).

70 See, e.g., Leiter Minerals, Inc. v. United States, 352 U.S. 220 (1957).

71 See Hilton v. Guyot, 159 U.S. I13, 165-66 (1895); Jackson v. Shuttleworth, 42 III. App. 2d 257, 258, 192 N.E.2d 217, 218 (1963); Labak v. Graznar, 54 Ohio App. 191, 194, 6 N.E.2d 790, 791-92 (1935). See also Note, 74 HARv. L. REv. 726, 726-27 (1961). 
regarded within the specific areas. The statute should be read, therefore, with a view to the equitable foundations of the desired federal injunction.

\section{B. The Federal Court Prohibition and Traditional Grounds for Anti- Suit Injunctions}

Applying the equitable standards governing injunctions in the statestate area to federal-state cases, it will be seen that federal courts are empowered to enjoin proceedings before state courts in many, if not most, of the situations where state courts can do so, and often for the same reasons.

1. Relitigation. In the "relitigation" area it is now clear that federal courts may enjoin attempts to relitigate in state courts matters finally adjudicated in the federal courts. ${ }^{2}$ This is the import of the exception in section 2283 allowing a federal court injunctive power "to protect or effectuate its judgments" and of the Reviser's assertion that the section specifically overrules the Toucey decision, which had eliminated the judicially created relitigation exception. ${ }^{73}$

Although the language of the section seems to be concerned primarily with upholding the adjudicative powers and dignity of the federal courts, ${ }^{74}$ the cases granting injunctions after the enactment of section 2283 have also been concerned with the traditional equitable factors justifying the injunction. Thus, in Jackson $v$. Carter Oil Co., ${ }^{75}$

72 Allied Mut. Ins. Co. v. Roberson, 306 F.2d 130 (4th Cir. 1962); American Nat'l Bank \& Trust Co. v. Taussig, 255 F.2d 765 (7th Cir.), cert. denied, 358 U.S. 883 (1958); Jacksonville Blow Pipe Co. v. RFC, 244 F.2d 394 (5th Cir. 1957) (alternative holding); Berman v. Denver Tramway Corp., 197 F.2d 946 (I0th Cir. 1952); Jackson v. Carter Oil Co., 179 F.2d 524 (10th Cir.), cert. denied, 340 U.S. 812 (1950); NLRB v. Sunshine Mining Co., 125 F.2d 757 (9th Cir. 1942).

73 H.R. REP. No. 308, 80th Cong., 1st Sess. A181 (1948). "The exceptions specifically include the words 'to protect or effectuate its judgments,' for lack of which the Supreme Court held that the Federal courts are without power to enjoin relitigation of cases and controversies fully adjudicated by such courts. (See Toucey v. New York Life Insurance Co.,....)."

74 In this connection, note the case of Berman v. Denver Tramway Corp., 197 F.2d 946 (10th Cir. 1952), where the court affirmed a district court injunction to bar the prosecution of a state court action involving the nature of certain ordinances relating to maximum rates for fares. The court of appeals had finally adjudicated this issue twenty-five years previously in a suit involving a different plaintiff and cause of action. The court stated: "A federal court is clothed with power to secure and preserve to parties the fruits and advantages of its judgment or decree. In the appropriate exercise of that power, the court has jurisdiction through means of a supplemental proceeding to enjoin the relitigation in a state court of a matter litigated, determined, and adjudicated by its valid decree regularly entered, if the result of the relitigation would be to destroy the effect of the decree rendered in the United States Court." 197 F.2d at 950.

75179 F.2d 524 (10th Cir.), cert. denied, 340 U.S. 812 (1950). 
the Tenth Circuit upheld a federal court injunction barring a Seminole Indian from relitigating, through the device of having a guardian appointed, the matter of his identity as an allottee of certain oil-bearing lands. The same question had been decided against this plaintiff in a number of previous cases, and the court, although speaking in terms of protecting prior federal judgments, was clearly aware of the vexatious nature of these numerous suits. ${ }^{76}$

In deciding whether to issue an injunction under the relitigation exception in section 2283, the federal courts will often reach the same results as would a state court in enjoining proceedings to prevent relitigation before another state court. But while the state court would base its decision on strictly equitable grounds and thus, for example, deny the injunction if an alternative remedy such as res judicata would protect the rights of the equity plaintiff, the federal courts have enjoined automatically whenever there is a prior federal judgment. 77 This practice thwarts the principles of equity underlying the issuance of any injunction, and may foster the unnecessary interference which section 2283 is designed to prevent. In deference to the state courts, if for no other reason, the federal courts should give greater weight to equitable factors before exercising their injunctive powers.

2. Fraud or Collusion. Prior to the Toucey decision federal courts could enjoin the enforcement of fraudulently obtained state court judgments, ${ }^{78}$ but could not enjoin the prosecution of pending state court proceedings tainted by fraud or collusion. ${ }^{79}$ The rationale for this distinction was that the enforcement of judgments did not come within the term "proceedings" found in the statutory prohibition. 80

76 In its statement of the case the court notes that "the matter has been in the courts since 1932 and this is the third time it has been before this court. . . . In the numerous actions, including this one, the appellant maintained that he was the Raymond Jackson to whom the land was allotted and that he was being deprived of the lands and the proceeds thereof by fraud and collusion. Each time these questions were presented to the trial court there resulted a finding and final judgment that he was not the allottee but was an imposter." 179 F.2d at 525.

77 Compare Oates v. Morningside College, 217 Iowa 1059, 252 N.W. 783 (1934) with American Nat'l Bank \& Trust Co. v. Taussig, 255 F.2d 765 (7th Cir.), cert. denied, 358 U.S. 883 (1958).

78 Wells Fargo \& Co. v. Taylor, 254 U.S. 175 (1920); Simon v. Southern Ry., 236 U.S. 115 (1915); cf. Marshall v. Holmes, 141 U.S. 589 (1891).

79 Essanay Film Co. v. Kane, 258 U.S. 358 (1922); Western Union Tel. Co. v. Tompa, 51 F.2d 1032 (2d Cir. 1931).

80 In Simon v. Southern Ry., 236 U.S. 115 (1915), Mr. Justice Lamar, writing for the Court, sustained a federal court injunction against the enforcement of an allegedly fraudulent state court judgment, stating: "when the litigation has ended and a final judgment has been obtained-and when the plaintiff endeavors to use such judgmenta new state of facts, not within the language of the statute may arise." Id. at 124. And in Essanay Film Co. v. Kane, supra note 79, the Court drew this distinction even more 
The vitality of this exception is presently unclear. Neither section 2283 nor the Reviser's Note makes specific reference to it, although the Note concludes with a sweeping assertion of full restoration of preToucey law. However, Mr. Justice Frankfurter in Toucey noted in a dictum that since the exception was based on a distinction that was no longer viable in light of the broad interpretation of "proceedings" which had recently been set forth by the Court, "the foundation of these cases is thus very doubtful." 81 This implies that the exception had expired before Toucey, and was not in a position to be restored. Professor Moore, on the other hand, argues strenuously that this exception still exists and can be reconciled with the statute and cases.82 Lower federal courts have divided on this issue, but without an authoritative holding. ${ }^{83}$

Even in Moore's analysis, however, the allowance of a federal injunction is limited to preventing the enforcement of fraudulent state court judgments, and the old distinction thought to be necessitated by the language of the statute is perpetuated. This distinction has been defended on two grounds: (1) that injunctions to bar the enforcement of judgments do not create the direct interference with the judicial processes of a state court which the statute was designed to prevent; and (2) that since judgments obtained through fraud are considered void, they are open to attack in all courts regardless of the nature of

clearly in refusing to enjoin pending state court proceedings in which fraud was involved.

81314 U.S. at 136. Mr. Justice Frankfurter referred to Hill v. Martin, 296 U.S. 393, 403 (1935), where the Court stated that the term "proceedings" in the statute encompassed "all steps taken or which may be taken in the state court or by its officers from the institution to the close of the final process." The Court, however, specifically recognized that fraudulent injunctions constituted an exception to this generalization. 296 U.S. at 403 \& n.19. Furthermore, the Hill case is clearly distinguishable on its facts. The question before the Court-and one that was answered affirmatively-was only whether an action in a state court brought by the state tax commissioner to determine the fact and amount of any estate tax due, with a second action required for collection, constituted judicial proceedings within the statute.

827 Moore, Federal Practice ff 60.39[1], 60.39[2], at 644, 648 (2d ed. 1955).

83 Statements of the non-existence of this exception were made in Collins v. Laclede Gas Co., 237 F.2d 633 (8th Cir. 1956) and Nongard v. Burlington County Bridge Comm'n, 229 F.2d 622 (3d Cir. 1956). The contrary was implied in Greyhound Corp. v. Leadman, 112 F. Supp. 237 (E.D. Ky. 1953). Professor Moore distinguishes both the Nongard and Laclede decisions on the grounds that these cases involved plaintiffs seeking to relitigate in a federal court issues previously adjudicated in state courts, and that the refusal of the federal court to enjoin was therefore proper. But if the state court judgment was really void due to fraud, there would seem to have been no prior valid adjudication in the state court, and therefore the party cannot be said to be relitigating in the federal court. See 1A Moore, Federal Practice $\int 0.226$, at 2622-26 (2d ed. 1961). See also Amalgamated Clothing Workers v. Richman Bros. Co., 348 U.S. 511, 523 (1955) (Warren, C.J., dissenting); Note, 74 HARv. L. REv. 726, 728 (1961). 
the specific court. ${ }^{84}$ However, since the policy underlying the statute is the prevention of unnecessary friction and ill feelings and the preservation of the independence of co-existent judicial systems, an injunction which in any way attempts to restrict the actions and powers of a state court engenders such friction, regardless of the stage of the state suit. Moreover, federal courts have considered the effectuation of their own judgments as part of their judicial proceedings, and have enjoined state court proceedings which threatened to interfere and to thwart these prior results. ${ }^{85}$

If an injunction is justified to prevent irreparable harm due to fraud in the state suit, it should be allowed as to both pending and completed state proceedings as is the case between state courts. But an injunction against pending proceedings can only be reconciled with the language of section 2283 if the federal court has prior jurisdiction over the controversy on the merits, since an ancillary injunction to bar fraudulent state proceedings would then be "in aid of its jurisdiction." Since federal courts otherwise possess full equity power ${ }^{86}$ and "original" federal injunctions have been permitted to bar the enforcement of fraudulent. judgments, 87 the original-ancillary distinction required by the statute seems artificial. Because fraud or collusion wholly vitiates any presumption of good faith or bona fide cause in the state suit and can impose inequitable burdens in many cases, it seems that a clear statutory exception is needed.

3. Public Policy. Federal injunctions against state court proceedings are permitted by section 2283 when "expressly authorized by Act of Congress." 88 This area is perhaps not as much an example of true "public policy" as it is of the supremacy of federal law, although the particular congressional authorization is certainly an expression of policy. The issuance of the injunction in this area has turned on a determination of exactly what is meant by "expressly"-i.e., how express must be the language in the particular Act of Congress. In Richman the Supreme Court took the view that while the particular statute need not refer explicitly to section 2283, it must show that

84 See Wells Fargo \& Co. v. Taylor, 254 U.S. 175 (1920); Simon v. Southern Ry., 236 U.S. 115 (1915). See also 1A MOORE, FEderal Practice f 0.226, at 2625 (2d ed. 1961); Note, supra note 83 , at 728 .

85 See Julian v. Central Trust Co., 193 U.S. 93 (1904); Central Nat'l Bank v. Stevens, 169 U.S. 432 (1898); Riggs v. Johnson County, 73 U.S. (6 Wall.) 166 (1867).

86 See Note, supra note 83 , at $726-27$.

87 E.g., Wells Fargo \& Co. v. Taylor, 254 U.S. 175 (1920); Simon v. Southern Ry., 236 U.S. 115 (1915).

8828 U.S.C. § 2283 (1958). Capital Service, Inc. v. NLRB, 347 U.S. 501 (1954) (National Labor Relations Act); Bowles v. Willingham, 321 U.S. 503 (1944) (Emergency Price Control Act); Dilworth v. Riner, 342 F.2d - (5th Cir. 1965) (Civil Rights Act of 1964). 
Congress clearly contemplated the use of the remedy. ${ }^{89} \mathrm{~A}$ more liberal approach was suggested by the Fourth Circuit in Baines v. City of Danville, ${ }^{90}$ which purported to follow Richman. There, the court denied an injunction under the Givil Rights Act of 1957 because there was no indication that the remedy was "antipathetic to statutory or judicially recognized limitations upon its exercise." The court indicated, thus, that the necessary statutory authorization may be "implicit," but only if the statutes "were, at the least, thoroughly incompatible with a literal application of the anti-injunction statute"91 -where the necessity to bar state court proceedings was a necessary corollary to the power and provisions of the particular federal statute..$^{92}$

Federal injunctions restraining subsequent state court proceedings on a cause of action removed to a federal court have long been upheld. ${ }^{93}$ This exception was judicially created, but was incorporated by Congress in section 2283, which permits the federal court to enjoin "where necessary in aid of its jurisdiction." 94 By not including removal in the general "Act of Congress" exception, Congress indicated that the language of the Removal Acts was not sufficiently "express," 95 an implication that would seem contrary to the interpretation of the Baines court. 96

89 Amalgamated Clothing Workers v. Richman Bros. Co., 348 U.S. $511,516-18$ (1955). 90337 F.2d 579 (4th Cir. 1964).

$91 \mathrm{Id}$. at 589. See Note, 50 VA. L. REv. 1404 (1964).

92 The result of these cases is again a relatively flexible interpretation of the actual language of $\S 2283$. If such liberty is to be condoned, it can only be justified where equity otherwise requires the injunctive remedy. The dissent in the Baines case found congressional authorization for an injunction in the 1957 Civil Rights Act and emphasized the underlying equitable and policy considerations, noting "that First Amendment rights of the entire Negro community would . . . be irreparably injured" if the state prosecutions were allowed to proceed. "Comity does not require the federal courts to sit idly by when only an equitable remedy can effectively protect these rights. . . . It is the duty of the federal courts to protect these rights, and the statute, 42 U.S.C.A. $\S 1983$, expressly authorizes equitable relief. . . . Since it is obvious that in the context of this case no other civil remedy could possibly accomplish the Congressional purpose to afford the Negro citizen equal rights, there is every reason to hold that the equitable remedy expressly authorized in 42 U.S.C.A. $\$ 1983$ is within the exception set forth in 28 U.S.C.A. \& 2283." 337 F.2d at 601. See also Dilworth v. Riner, 342 F.2d - (5th Cir. 1965), where the Civil Rights Act of 1964 was found to provide the requisite authorization to enjoin state court proceedings and Baines was distinguished.

93 Madisonville Traction Co. v. Saint Bernard Mining Co., 196 U.S. 239 (1905); Dietzsch v. Huidekoper, 103 U.S. 494 (1881).

94 See Reviser's Note, H.R. REP. No. 308, 80th Cong., Ist Sess. A181 (1948).

95 The removal provisions, 28 U.S.C. $\$ 1446$ (e) (1958), state only that "the state court shall proceed no further unless and until the case is remanded." This is certainly "incompatible" with any further state court proceedings, but does not refer to the use of an injunction.

96 In Baines the court referred expressly to the Removal Acts as an example of implied injunctive power in a federal statute. $337 \mathrm{~F} .2 \mathrm{~d}$ at 589 . See notes 92,95 supra. 
When the United States seeks the injunction in its sovereign capacity, "to prevent threatened irreparable injury to a national interest," Supreme Court in Leiter Minerals, Inc. v. United States ${ }^{88}$ held that section 2283 did not apply. Mr. Justice Frankfurter, for the Court, stated that "the frustration of superior federal interests that would ensue from precluding the Federal Government from obtaining a stay of state court proceedings except under the severe restrictions of 28 U.S.C. $\S 2283$ would be so great that we cannot reasonably impute such a purpose to Congress from the general language of 28 U.S.C. $\S 2283$ alone."99

Another pre-Toucey exception to the federal prohibition which was not specifically mentioned in section 2283 or in the Reviser's Note apparently existed when state courts or officials attempted to enforce unconstitutional statutes or ordinances. In the leading case of Ex parte Young 100 a state official was enjoined from bringing an action to enforce a statute setting extremely low intra-state railroad rates and imposing severe penalties for violations. The Court did not refer to the federal injunction prohibition but alluded instead to the general exemption of criminal proceedings from equity jurisdiction. The Court found an exception to this exemption where the court of equity had jurisdiction prior to the institution of the criminal prosecution and thus affirmed the injunction. But in a dictum Mr. Justice Peckham also noted that the federal court could not interfere by injunction with proceedings already pending in the state court.101

The implications of this dictum have led to a distinction between pending and completed state suits similar to that which evolved in the area of fraud. ${ }^{102}$ Thus, it has been thought that the federal prohibition

97 Leiter Minerals, Inc. v. United States, 352 U.S. 220, 225-26 (1957).

98352 U.S. 220 (1957). Other cases include United States v. Wood, 295 F.2d 772 (5th Cir. 1961), cert. denied, 369 U.S. 850 (1963); United States v. Inaba, 291 Fed. 416 (E.D. Wash. 1923). But where the United States is not acting in its sovereign capacity but merely is a private party the prohibition of $\$ 2283$ will apply. United States v. Bank of N.Y. \& Trust Co., 296 U.S. 563 (1936); Eden Memorial Park Ass'n v. United States, 300 F.2d 432 (9th Cir. 1962).

99 Id. at 226. Again, the proclivity of the federal courts to develop exceptions to the language of the statute is revealed, this time primarily on the basis of policy. These developments, however, seem inevitable with a statute which rests upon comity and which clearly recognizes certain exceptions even within its own language. In Leiter Mr. Justice Frankfurter, usually one of the strongest proponents of a strict interpretation and firm inter-court controls, performed the service. Compare with Leiter his statement in Richman: "By that enactment, Congress made clear beyond cavil that the prohibition is not to be whittled away by judicial improvisation." 348 U.S. at $\mathbf{5 1 4}$.

100209 U.S. 123 (1908).

101 Id. at 162.

102 See Note, supra note 83 , at $728-29$. 
did not apply where state court proceedings to enforce an unconstitutional statute were not actually pending, but only threatened, since the direct interference contemplated by the statute did not result. Nevertheless, the artificiality of this distinction seems as apparent here as in the fraud area. ${ }^{103}$ An injunction would seem to be a possible remedy if necessary to prevent irreparable harm in the case of both pending and threatened state proceedings. ${ }^{104}$ Authorization for this remedy is not found in section 2283, and would have to be based on a finding of the superior interest in upholding the Constitution-taking the position either that Congress could not have intended in any way to subordinate this goal, and thus did not contemplate a situation such as Young, or that Congress in any case does not have the power, even if it so intended, to thwart the Constitution. Since many of the injunctions in this area are sought by the United States, under Leiter Minerals section 2283 is inapplicable in either case. ${ }^{105}$

Most of the recent litigation involving "public policy" considerations has arisen where exclusive federal jurisdiction is alleged by a party to the state court proceeding. ${ }^{106}$ In the leading case of Amalgamated

103 See text accompanying notes 84-85 supra; Comment, 35 CALIF. L. REv. 545, 552 (1947). The Comment states that since the original basis of the distinction was one arising out of in rem proceedings, where the court first taking jurisdiction of the res could prevent any subsequent interference by other courts, and since this rule is no longer applicable to proceedings in personam, the distinction should be re-examined. "It is at odds with the general requirement of immediately threatened irreparable injury. The actual pendency of state enforcement suits is the best evidence of threatened injury, and the interference with the state government is virtually the same whether injunctions are issued before or after state judicial action has commenced. Unless section 265 [predecessor to $\$ 2283$ ] is interpreted as not to bar the institution of any suits, the constitutional exception should be made general or dropped altogether."

104 In Douglas v. City of Jeannette, 319 U.S. 157 (1943), the Supreme Court refused to allow a federal injunction to bar the prosecution of threatened criminal proceedings in a state court under a statute that had previously been held unconstitutional. The Court stated that the grounds for equity intervention into criminal proceedings must be "only on a showing of danger or irreparable injury, "both great and immediate.'" $I d$. at 164. This formula was applied to allow an injunction against a pending criminal prosecution under a local labor ordinance in Denton v. City of Carrollton, 235 F.2d 481, 484 (5th Cir. 1956).

105 See cases cited note 98 supra. Such a case is United States v. Wood, 295 F.2d 772 (5th Cir. 1961), cert. denied, 369 U.S. 850 (1962). There a federal court injunction was allowed to bar the prosecution of a breach of the peace action against a Negro who had been assisting in the registration of voters in Mississippi. One ground for the injunction was the fact that the suit had been brought by the United States to protect federal interests (the right to register to vote). An alternative ground was that the Civil Rights Act of 1957 was intended to cover such situations and that an injunction was one of the remedies it provided. Thus, the "Act of Congress" exception was invoked. See Recent Developments, 62 ColuM. L. REv. 901 (1962). But see, as to the latter point, Baines v. City of Danville, 337 F.2d 579 (4th Cir. 1964).

106 See Kochery, Conflict of Jurisdiction: 28 U.S.C. $\S 2283$ and Exclusive Federal Jurisdiction. 4 Buffalo L. Rev. 269 (1955); Note, 48 Nw. U.L. Rev. 383 (1953). 
Clothing Workers v. Richman Bros. Co., ${ }^{107}$ the Supreme Court affirmed a federal court's denial of a union request to enjoin an employer's state court suit which sought to enjoin union picketing and other activity. The Court, in an opinion by Mr. Justice Frankfurter, held that such an injunction did not fall within any of the exceptions in section 2283. The Taft-Hartley Act was held to allow injunctions generally, but only on application by the National Labor Relations Board, and thus no "express" congressional authorization was found.108 Secondly, since the Board had primary jurisdiction over labor disputes, the Court ruled that the Board must first invoke the jurisdiction of the district court before that court could enjoin "in aid of its jurisdiction."109 Most important for the purposes of this discussion, the Court rejected the union's third contention for an injunction, namely "that section 2283 does not apply whenever the moving party in the District Court alleges that the state court is "wholly without jurisdiction over the subject matter, having invaded a field pre-empted by Congress.' "110 The Court based its conclusion on its reading of section 2283 as codifying existing law and precluding the courts from developing further exceptions. Even granting that Congress may have intended to restore all pre-Toucey law, the Court found no established exception for "exclusive jurisdiction."111

Although it is often quite difficult to ascertain what exactly is within the exclusive jurisdiction of the federal courts and agencies, in cases where such jurisdiction is found a federal injunction against state court proceedings should be granted.112 The usurpation of authority by state

107348 U.S. 511 (1955).

$108 \mathrm{Id}$. at 516.

109 Id. at 519-20. (Emphasis added.) Compare Amalgamated Clothing Workers v. Richman Bros. Co., 348 U.S. 511 (1955) with Capital Serv., Inc. v. NLRB, 347 U.S. 501 (1954). In Capital Service the union first filed with the National Labor Relations Board to bar the employer's suit in a state court to enjoin union picketing. The Board then brought the action in a federal court for an injunction, which was granted and affirmed by the Supreme Court.

110348 U.S. at 515. The Court made the assumption that the subject matter was one wholly outside the control or jurisdiction of the state court, and decided the case on this assumption. Id. at 514 .

111348 U.S. at 514. But see Warren, G.J., dissenting, id. at 521-23; Kochery, supra note 106.

112 See Weber v. Anheuser-Busch, Inc., 348 U.S. 468, 480 (1955). Professor Moore suggests that where a state court has prior jurisdiction in an action on a contract, for example, to which violation of the anti-trust laws, a matter of exclusive federal jurisdiction, is pleaded as a defense, there should be no federal injunction. See Lyons v. Westinghouse Elec. Corp., 201 F.2d 510 (2d Cir.), cert. denied, 345 U.S. 923 (1953); Red Rock Cola Co. v. Red Rock Bottlers, Inc., I95 F.2d 406 (5th Cir. 1952); Avon Publishing Co. v. American News Co., 143 F. Supp. 516 (S.D.N.Y. 1956). On the other hand, where state courts are dealing with matters wholly delegated by Congress 
courts in these cases is certainly injurious to national interests, and can often result in unconscionable harm to the individual party. In cases where exclusive federal jurisdiction is found such harm should be presumed and the issuance of the injunction should not depend on its proof. ${ }^{113}$

The injunction may be justified on one of two grounds. First, it would seem to be "necessary in aid of [the federal court's] jurisdiction." However, Richman implies that such jurisdiction would have to be invoked by the body possessing exclusive jurisdiction, ${ }^{114}$ and possibly would be further restricted to cases where the injunction sought was ancillary to a pending hearing on the merits of the case.115 For these reasons the second is the better ground-that section 2283 was never intended to apply in cases of exclusive federal jurisdiction. Support for this conclusion may be found by drawing an analogy to the situation where injunctions are sought by the United States to protect "national interests." 116 The supremacy of federal law also supports this position.

4. Multiplicity of Actions and Concurrency. As in the state-state cases, a federal court should be extremely reluctant to enjoin proceedings before a state court merely because a suit on the same cause is also being heard in the federal court. Although the injunction could be justified as arguably "in aid of [the federal court's] jurisdiction,"117 its issuance would virtually emasculate section 2283. Such action would also foster direct interference with pending state judicial proceedings,

either to federal courts or agencies, no benefit and much potential harm will result from allowing the parties to proceed in the state court or to enforce a state court judgment. See FTC v. St. Regis Paper Co., 304 F.2d 731 (7th Cir. 1962); Bland Lumber Co. v. NLRB, I77 F.2d 555 (5th Cir. 1949). See generally IA Moore, FEDERAL Practice $\mid 0.208$ [4], at 2324-25 (2d ed. 1961).

113 As in the case of injunctions sought by the United States, an injunction to protect the exclusive jurisdiction of the federal courts is primarily a matter of policy and should not necessarily be linked to equity. The chief harm here is to national interests and power, and the equities of the particular case are secondary. In practically every case harm to the defendant in the wrongful state court suit would seem to be presumable and all but impossible to counter.

114348 U.S. at 519-21. See note 109 supra.

115 See Capital Service, Inc. v. NLRB, 347 U.S. 501 (1954); Bowles v. Willingham, 321 U.S. 503 (1944). See also text accompanying notes 86-87 supra.

110 This is the conclusion reached by Kochery, supra note 106, after an excellent and thorough analysis of the Richman case and $\S 2283$.

117 The injunction might be in aid of the jurisdiction of the federal court where it had taken jurisdiction over the whole controversy and an ancillary injunction was needed to prevent external interference in other courts and to preserve the justiciability of the cases. See American Ins. Co. v. Lester, 214 F.2d 578 (4th Cir. 1954) (dictum). But see Georgia Power Co. v. Hudson, 49 F.2d 66 (4th Cir. 1931) (alternative holding); Leshem v. Continental Am. Life Ins. Co., 219 F. Supp. 504 (S.D.N.Y. 1963). 
which all courts have recognized as forbidden and which led to the "pending-completed" state action distinction, ${ }^{118}$ without the policy goals present in the removal and exclusive jurisdiction areas and without the clear evidence of inequitable and vexatious motivation present in the relitigation area.118 Again, as in the state-state relationship, the difficulty with concurrency lies in the problem of proving a vexatious motive in bringing multiple actions, since there are often valid reasons for multiplicity.120 Thus, in Kline v. Burke Coinstr. Co., ${ }^{121}$ the Supreme Court held that a federal court could not enjoin a concurrent action involving the same issues brought by the defendant in the federal suit for purposes of protecting its own prior jurisdiction, stating:

Each court is free to proceed in its own way and in its own time, without reference to the proceedings in the other court. Whenever a judgment, is rendered in one of the courts and pleaded in the other, the effect of that judgment is to be determined by the application of res adjudicata by the court in which the action is still pending . . . . 122

Some tolerance of duplicative and wasteful litigation would seem to be the necessary price for maintaining harmonious federal and state court relations. Even when the state court suit can clearly be shown to be vexatious, a federal injunction is difficult to reconcile with the statute, absent a general equity exception. Such an exception, as has been noted, would be uncontrollable, and render the statute meaningless. ${ }^{123}$ Instead, the evils of multiplicity between federal and state

118 See text accompanying notes 79-80, 84, 102 supra.

119 Injunctions under the removal or relitigation exceptions would seem to be in furtherance of federal policy in that they are expressly permitted under $\$ 2283$. An injunction to prevent relitigation can be further justified on equitable grounds, insofar as absence of a bona fide cause of action and good faith may be inferred from the attempted evasion of a prior final judgment. Similar analysis could be applied to injunctions in removal situations-that an attempt to continue in a state court is evidence of bad faith. It is unfortunate, however, that Congress did not include the removal exception under the "Act of Congress" rather than under the "in aid of its jurisdiction" phrase in $\S 2283$. Continued proceedings in a state court are incompatible with removal. 28 U.S.C. \& 1446(e) (1958). See text accompanying notes 91-92 supra. The use of a general "jurisdiction" phrase leads to difficulties in the multiplicity area, where injunctions may also be ancillary, and creates problems relating to the apparently greater rights of a defendant in a federal court on removal over a plaintiff in an original federal suit, since the latter generally cannot obtain an anti-suit injunction. See generally Toucey v. New York Life Ins. Co., 314 U.S. 118, I33 (1941); Taylor \& Willis, The Power of Federal Courts to Enjoin Proceedings in State Courts, 42 YALE L.J. 1169, 1172-75 (1933).

120 See Vestal, Reactive Litigation, 47 IowA L. REv. 11, 24 (1961); Note, 60 Colum. L. REv. 684, 698-709 (1960).

121260 U.S. 226 (1922).

$122 I d$. at 230.

123 See text accompanying notes 70-71 supra. 
courts should be combatted by the alternative devices of abatement or stay by the second court, consolidation and the compulsory counterclaim, and the doctrines of forum non conveniens and judicial abstention.124

\section{The State Court Prohibition}

\section{A. Development and Interpretation}

The prohibition on state court injunctions to bar federal proceedings is the product of judicial decisions, both state and federal, and undoubtedly arises out of the same considerations of comity and independence which motivated the federal statutory prohibition. ${ }^{125}$ Indeed, the early development of both prohibitions was frequently in terms of mutuality and reciprocity, ${ }^{126}$ with great weight being given to an 1836 statement of the rule by Mr. Justice Story. ${ }^{127}$

The state ban was first set forth in the 1812 Supreme Court case of McKim v. Voorhies. 128 There, a victorious plaintiff in an ejectment suit before a federal court was denied a writ of habere facias possessionem by the clerk of that court. the clerk having been enjoined from issuing the writ by a state court on the defendants' bill. The Court held that the writ of habere facias must issue, and added, by way of a strong dictum, that "the State Court had no jurisdiction to enjoin a judgment of the Circuit Court of the United States."129 Later, in Riggs v. Johnson County, ${ }^{130}$ the Court stmilarly invalidated a state court injunction as an encroachment on a prior federal court judgment. The federal

124 See Vestal, supra note 120, at 18-28.

125 See generally Toucey v. New York Life Ins. Co., 314 U.S. 118, 129-32 (I941) (Frankfurter, J.); Warren, Federal and State Court Interference, 43 HARv. L. REv. 345 (1930).

126 Toucey v. New York Life Ins. Co., 314 U.S. 118, 135 (1941); Kline v. Burke Constr. Co., 260 U.S. 226, 235 (1922); Amy v. The Supervisors, 78 U.S. (II Wall.) 136 (1870); Prugh v. Portsmouth Sav. Bank, 48 Neb. 414, 67 N.W. 309 (1896); Keith v. Alger, 114 Tenn. 1, 85 S.W. 71 (1905). See generally Warren, supra note 125, at 359-68; Note, 90 U. PA. L. REv. 714 (1942).

1272 STORY, Equitry JuRISPRUdence 186 (Ist ed. 1836): "And it is now held, that whereever the parties are resident within a country, the Courts of that country have full authority to act upon them personally with respect to the subject of suits in a foreign country, as the end of justice may require . . . There is a recognized exception to this doctrine in America; and that is, that the State Courts cannot injoin proceedings in the Courts of the United States; nor the latter in the former. But this exception proceeds upon peculiar grounds of municipal and constitutional law, the respective courts being entirely competent to administer full relief in the suits pending therein." For a general discussion of this "dogma," its basis, and subsequent broad influence, see Note, State Injunctions Against Proceedings in the Federal Courts, 90 U. PA. L. REv. 714 (1942).

12811 U.S. (7 Cranch) 278 (1812).

129 Id. at 280.

13073 U.S. (6 Wall.) 166 (1867). 
court had issued a mandamus to require a county official to levy a tax to support a bond issue. After the issuance of the bonds, the state decided that the authorizing statute was illegal, and the state court, in a taxpayer's suit, enjoined the official from levying the tax. The Court, in striking down the injunction, stated:

State courts are exempt from all interference by the Federal tribunals, but they are destitute of all power to restrain either the process or proceedings in the national courts. Circuit courts and State courts act separably and independently of each other, and in their respective spheres of action the process issued by the one is as far beyond the reach of the other, as if the line of division between them "was traced by landmarks and monuments visible to the eye." 131

Similarly, in Central Nat'l Bank v. Stevens, ${ }^{132}$ the Court again held that a state court could not enjoin the execution of a federal court. judgment. The Court relied on Riggs among other cases and declared that the state court injunction "was a plain interference with the proceedings in another court . ..."133

Even while judicial exceptions were being carved into the absolute language of the federal statute, the state courts were still deemed incapable of enjoining proceedings before a federal court.134 And yet cases such as McKim, Riggs and Stevens, which are cited for this conclusion, do not support this broad prohibition. Except in the case of fraud, federal courts have been equally unable to enjoin the execution of state court judgments. ${ }^{135}$

131 Id. at $195-96$.

132169 U.S. 432 (1898).

$133 \mathrm{Id}$. at 459 .

134 Durfee \& Sloss, Federal Injunction Against Proceedings in State Courts: The Life History of a Statute, 30 Mrch. L. REv. 1145, 1149 (1932), in particular, advances the thesis that the period of nationalism and industrial growth following the Civil War generated political forces that led to the expansion of federal court powers in all areas. Similar reasoning would seem to explain the fact that corresponding exceptions were not developed at this time to the state court prohibition. Very few attempts were made to enjoin by state courts, probably because the state courts were just as cognizant of the prevailing political and industrial forces as the federal courts, and the situations in which exceptions might have been developed simply did not arise.

135 See Watson v. Jones, 80 U.S. (13 Wall.) 679 (1872); Randall v. Howard, 67 U.S. (2 Black) 585 (1862); Freeman v. Howe, 65 U.S. (24 How.) 450 (1860); Mills v. Provident Life \& Trust Co., 100 Fed. 344 (9th Cir. 1900). It has been suggested that in light of the more direct interference thought to be engendered by injunctions against pending court proceedings, these judgment cases-Riggs and Stevens-could embody an absolute prohibition, and that Donovan v. City of Dallas, 377 U.S. 408 (1964), was a natural conclusion from a reading of these cases. See Arnold, State Power to Enjoin Federal Proceedings, 51 VA. L. REv. 59, 69 (1965). However, this 
Despite the broad language setting forth the state ban, ${ }^{136}$ state court injunctions against the prosecution of federal suits have been upheld in a number of state cases. In many the ban on state injunctions was simply ignored, ${ }^{137}$ while in others the authority of cases like Riggs and Stevens was evaded or distinguished.138 Indeed, in the recent case of University of Texas $v$. Morris, ${ }^{139}$ the Texas Supreme Court affirmed the issuance of an injunction barring the further prosecution of a suit in a federal court in New Mexico. The court did not mention the state ban and based its decision solely on the equitable grounds for such an injunction.

Thus, historically, the conclusion is far from inescapable that state courts are absolutely without power to enjoin the prosecution of federal court actions. Both courts and commentators have suggested that this power does in fact exist, concluding that it has not been

argument appears to overlook several items: first, the reciprocal standing of the federal and state bans and the exceptions in the federal ban which have long been recognized and are now granted congressional sanction; second, although an injunction against the enforcement of a judgment may engender less interference and even be beyond the statutory prohibition, in the absence of a clear showing of irreparable harm due to equitable or constitutional grounds, federal courts have not enjoined the enforcement of state court judgments. These grounds have been found only where the state court judgment had been obtained through fraud, a situation that did not exist here. See, e.g., Wells Fargo \& Co. v. Taylor, 254 U.S. 175 (1920). Therefore, there is no showing that the Court in either Riggs or Stevens envisaged an absolute ban on state injunctions.

136 In Riggs v. Johnson County, 73 U.S. (6 Wall.) 166, 196 (1867), the Court stated: "Viewed in any light, therefore, it is obvious that the injunction of a State court is inoperative to control, or in any manner affect the process or proceedings of a Circuit court ...."

137 Karcher v. Burbank, 303 Mass. 303, 21 N.E.2d 542 (1939); Chambers v. Metropolitan Life Ins. Co., 236 Mo. App. 823, 157 S.W.2d 593 (1942); University of Texas v. Morris, 162 Tex. 60, 344 S.W.2d 427, cert. denied, 366 U.S. 973 (1961).

138 In Shaw v. Frey, 69 N.J. Eq. 321, 59 Atl. 811 (Ch. 1905), the vice chancellor, with specific reference to the Riggs and Stevens cases, stated that "the doctrine that a state court may never restrain a litigant in a federal court, cannot, in my opinion, be supported by the adjudications of the supreme court of the United States. .... I have been unable to find any adjudication that establishes so broad a principle." $I d$. at 324,59 Atl. at 812 . Following this decision, and attempting to reconcile it with Riggs and Stevens, later New Jersey cases have drawn a distinction between enjoining pending federal court proceedings (valid under Shaw) and enjoining the execution of federal court judgments (forbidden by Riggs and Stevens). See Fort v. The Lang Co., 118 N.J. Eq. 527, 180 Atl. 395 (Ch. 1935); Smith v. Reed, 74 N.J. Eq776,70 Atl. 961 (Ch. 1908). This result is the opposite of what logic would suggest in light of the general principles of non-interference, but its significance would seem to lie both in the importance with which state courts regard their injunctive powers and the refusal to accept either Riggs or Stevens as controlling authority for any absolute state court prohibition.

139162 Tex. 60, 344 S.W.2d 427, cert. denied, 366 U.S. 973 (1961). 
exercised primarily out of considerations of comity. ${ }^{140}$ In view of the now established exceptions to the federal statutory prohibition, it seems reasonable to conclude that a similar relaxation of the state prohibition is in order for reasons of reciprocity and the prevention of inequities. ${ }^{141}$

However, in its recent decision in Donovan v. City of Dallas, ${ }^{142}$ the Supreme Court in effect rejected this argument and, at the same time, re-affirmed the state court prohibition in broad terms. In this case, a class suit was brought in a Texas court to enjoin the construction of improvements to a municipal airport and to bar the issuance of municipal bonds to finance these improvements. Summary judgment was entered for the city, affirmed on appeal and review denied by the Supreme Court of Texas. The Supreme Court denied certiorari. Thereafter a suit based on the same allegations and with the same objectives was instituted in a federal district court. In an action by the city to enjoin the prosecution of this suit, the Supreme Court of Texas held that the injunction should issue, basing its decision wholly on the equitable grounds associated with relitigation, without reference to the state ban. ${ }^{143}$

The Supreme Court, in an opinion by Mr. Justice Black, reversed, holding that the Texas court was without injunctive power to affect proceedings in the federal court. The opinion was based on two grounds: first, that "while Congress has seen fit to authorize courts of the United States to restrain state-court proceedings in some special circumstances, it has in no way relaxed the old and well-established judicially declared rule that state courts are completely without power to restrain federal court proceedings in in personam actions like the one here"144; and second, that the plaintiffs had a right to be in a federal court-"a right which is theirs by reason of congressional enactments passed pursuant to

140 Baltimore \& Ohio R.R. v. Kepner, 314 U.S. 44, 56 (194I) (Frankfurter, J., dissenting); Bryant v. Atlantic Coast Line R.R., 92 F.2d 569, 571 (2d Cir. 1937) (L. Hand, J.); MOORE, Commentary on the U.S. Judicial CODE If 0.03[49], at 416-17 (1949); Kurland, Toward a Co-operative Judicial Federalism: The Federal Court Abstention Doctrine, 24 F.R.D. 481, 491 (1960).

141 Of the exceptions expressly noted in the Reviser's Note to $\$ 2283$, only that for relitigation is applicable to the situation of state court injunctions. The Act of Congress and removal exceptions are, of course, peculiar to the federal courts.

142377 U.S. 408 (1964).

143 In City of Dallas v. Dixon, 365 S.W.2d 919 (Tex. Sup. Ct. 1963), the Texas Supreme Court stated "we hold . . that exercise of such jurisdiction is mandatory when an actual interference with enforcement of the judgment is coupled with the second suit or when the mere prosecution of the suit destroys the efficacy of the judgment." 365 S.W.2d at 925 .

144377 U.S. $408,412-13$ (1964). 
congressional policy"145 - and that this "right was granted by Congress and cannot be taken away by the state." 146

The first of these grounds is certainly questionable. By implying that Congress, in relaxing only the federal court prohibition, intended the state prohibition to remain absolute, the Court ignores the fact that Congress has never addressed itself, one way or the other, to the state ban, even assuming that it has power over the state courts in this regard through indirect means. ${ }^{147}$ Indeed, since the federal bar was traditionally couched in terms of reciprocity, the fact that that ban was relaxed should argue for a similar relaxation of the state prohibition. Furthermore, the cases relied on by $\mathrm{Mr}$. Justice Black for this "well-established rule"McKim, Riggs and Stevens-do not support as broad a statement as he made ${ }^{148}$ and were readily disposed of in Mr. Justice Harlan's dissenting opinion. 140

The Court's second ground requires closer scrutiny. The proposition advanced is that parties properly before a federal court have a right to be there, a right granted by Congress which cannot be thwarted by state action. This is not a matter of the superiority of federal courts, but of the supremacy of federal law. ${ }^{150}$ If Congress intended to and did grant such an absolute right to a federal trial, then under the supremacy clause state law cannot defeat it.

The assertion of an "indefeasible right to a federal trial" has been raised most often in connection with the power of a federal court to stay or dismiss proceedings before it in favor of prior, concurrent state court proceedings involving the same issues and parties. ${ }^{151}$ The alleged

145 Id. at 412 .

146 Id. at 413 .

147 Conceivably, Congress could declare that an area of federal court jurisdiction is or is not amenable to state court injunctions, and thus indirectly affect state court power. However, it has never done so explicitly, and certainly not at all on the scale that the Donovan Court contemplated.

148 See text accompanying notes 128-35 supra.

149377 U.S. at 418-20. However, Mr. Justice Harlan does not address himself directly to the state ban, and sees Donovan as simply involving duplicative and vexatious litigation for which an injunction is an appropriate remedy between state courts.

150 The issue of federal court superiority is a recurrent one, raised most often in connection with removal and the greater federal habeas corpus power. It was dismissed as a general rule in areas of concurrent federal and state court jurisdiction in Kline v. Burke Constr. Co., 260 U.S. 226, 234-35 (1922): "it was . . equally the duty of the state court to take the case and proceed to judgment. There can be no question of judicial supremacy, or of superiority of individual right." See also Arnold, supra note 135 , at 71 .

151 Milk Drivers Union v. Dairymen's League Co-op. Ass'n, 304 F.2d 913 (2d Cir. 1962); P. Beiersdorf \& Co. v. McGohey, 187 F.2d 14 (2d Cir. 1951); Mottolese v. Kaufman, 176 F.2d 301 (2d Cir. 1949). Contra, Liberty Mut. Ins. Co. v. Pennsylvania 
"right," however, has been wholly the product of dicta and does not rest on any firm congressional mandate. ${ }^{152}$ Certainly, exceptions have been recognized by federal courts through abstention, ${ }^{153}$ stays $^{154}$ and forum non conveniens. ${ }^{155}$

However, it is one thing for a federal court to be able to stay or dismiss and entirely another for a state court to possess this control indirectly through its injunctive power. At stake here, it is felt, is the very independence of the federal courts-the purposes of diversity jurisdiction

R.R., 322 F.2d 963 (7th Gir. 1963); Mach-Tronics, Inc. v. Zirpoli, 316 F.2d 820 (9th Cir. 1963). See generally Note, 60 Colum. L. REv. 684 (1960); Note, 59 YALE L.J. 978 (1950). A distinction can perhaps be drawn where the federal court has not stayed its proceeding in deference to the prior state court action, but has dismissed. In the latter situation, the federal court action has been held improper. Liberty Mut. Ins. Co. v. Pennsylvania R.R., supra.

152 See generally Note, 59 YALE L.J. 978, 980 (1950). Apparently the first statement of this "right" was in a dictum by Mr. Chief Justice Marshall. Cohens v. Virginia, 19 U.S. (6 Wheat.) 264, 403 (1821). The strongest statement after this occurred in McClellan v. Carland, 217 U.S. 268, 283 (1910). Again only dictum was involved, to the effect that a federal court could not stay proceedings before it when they were prior in time to the state court proceedings. See also Kline v. Burke Constr. Co., 260 U.S. 226, 234-35 (1922); Chicot County v. Sherwood, 148 U.S. 529, 534 (1893).

153 The doctrine of equitable abstention has frequently been before the Supreme Court in recent years. It involves allowing a federal court to stay or even dismiss actions before it which turn on unsettled questions of state law, in order to permit the state courts to rule on these questions. Most of the cases have dealt with the interpretation of allegedly unconstitutional state statutes or local ordinances. England v. Board of Medical Examiners, 375 U.S. 411 (1964), is the most recent case in this field. See generally Kurland, Toward a Co-operative Judicial Federalism: The Federal Abstention Doctrine, 24 F.R.D. 481 (1960); Wright, The Abstention Doctrine Reconsidered, 37 Texas L. Rev. 815 (1959); Note, 59 Colum. L. Rev. 749 (1959); Note, 108 U. PA. L. REv. 226 (1959).

154 Where admiralty jurisdiction was involved and the state court had prior jurisdiction in a suit against an owner, it was held that the federal court should have stayed its action. Langnes v. Green, 282 U.S. 531 (1931). And where the federal court action was for a declaratory judgment, the Supreme Court has held that the action should be dismissed where the issues were capable of resolution in a prior pending state court action. Brillhart v. Excess Ins. Co. of America, 316 U.S. 491 (1942). There are indications of the attitude of at least one present member of the Court on this practice. In England v. Board of Medical Examiners, 375 U.S. 411, 430 \& n.2 (1964), a case involving a ramification of the abstention doctrine, $\mathrm{Mr}$. Justice Douglas, in a concurring opinion urging a full review of the doctrine, referred in a footnote to the fact that "some federal courts have used the doctrine to shuttle over to state courts cases properly in the federal court yet not involving constitutional issues dependent on the meaning of state law (see Mottolese v. Kaufman, 176 F.2d 301 [2d Cir. 1949]; Beiersdorf \& Co. v. McGohey, 187 F.2d 14 [2d Cir. 1951])-decisions which baldly deny a suitor the remedy granted by Congress because it is not convenient to the district judge to decide the case."

155 Norwood v. Kirkpatrick, 349 U.S. 29 (1955); Gulf Oil Co. v. Gilbert, 330 U.S. 501 (1947). Presently, 28 U.S.C. $\S 1404$ (1958) recognizes this transfer to another federal court, maintaining federal jurisdiction. 
in particular may be abrogated. ${ }^{\mathbf{1 5 6}}$ However, state injunctions are recognized as valid in some areas, especially in cases involving in rem jurisdiction ${ }^{157}$ and perhaps in FELA actions. ${ }^{158}$ As has been noted, Congress has not dealt with state injunctive power and has not granted immunity from state injunctions to all federal litigants. ${ }^{159}$ In section 2283 it has recognized the necessity of limited federal interference with state court proceedings. Where Congress by means of exclusive federal jurisdiction or other direction has not segregated important national interests, ${ }^{160}$ notions of mutuality and reciprocity would seem to require that if a federal court can enjoin the prosecution of proceedings before a state court, the state court should be similarly empowered.161

Thus, the double standard espoused in Donovan should not be maintained. It has no basis in history or logic, and its effect will be to favor certain litigants at the expense of others. Moreover, the double standard will inevitably result in a diminution of the dignity and power of the state courts, since they, unlike the federal courts, will be unable to protect their judgments or jurisdiction in many cases. The equality and mutual respect upon which the two systems of courts are founded must be adversely affected.162 It would seem, then, that the state court prohibi-

156 See Brillhart v. Excess Ins. Co. of America, 316 U.S. 491, 501-02 (1942) (Stone, C.J., dissenting). See also State v. Frost, 113 Wis. 623, 652, 89 N.W. 915, 922 (1902): "It cannot be doubted that the jurisdiction of the federal court depends wholly upon the constitution and laws of the United States . . . ."

157 E.g., Princess Lida v. Thompson, 305 U.S. 456 (1939).

158 See Blanchard v. Commonwealth Oil Co., 294 F.2d 834 (5th Cir. 1961), where a federal court in an FELA action was held bound on the basis of comity to give effect to a state court anti-suit injunction. The validity of this case after Donovan, however, is certainly doubtful.

159 See text accompanying note 147 supra.

160 One argument that can be advanced here is that the federal courts provide a "haven" in some areas. Civil rights affords a prominent example today and was explicitly raised by the Donovan petitioners as an example of the "horribles" that might flow from permitting any state court injunctive power. Brief for Petitioners, p. 23, Donovan v. City of Dallas, 377 U.S. 408 (1964). However, while this argument may have merit in particular cases, the sweeping generalization advanced in Donovan is unwarranted. Specific areas which require such protection should be delineated by Congress. It is arguable that Congress has so acted where it has granted exclusive jurisdiction to federal courts and agencies. Even if these acts do not specifically grant injunctive power to the federal courts, it is altogether another thing to say that state courts can enjoin in these fields. Cf. United States v. Wood, 295 F.2d 773 (5th Cir. 1961), cert. denied, 369 U.S. 850 (1962). To hold state courts without power to enjoin parties to federal proceedings is different from holding them without power in cases such as Donovan, where state courts exercise concurrent jurisdiction and have a clear right to proceed. See Kline v. Burke Constr. Co., 260 U.S. 226 (1922).

161 See generally Hart \& Weghsler, Federal Courts and the Federal System $38-40$ (1953).

162 Perhaps the most authoritative discussion of the equality of the federal and state courts in areas of concurrent jurisdiction is that by Hamilton in The Federalist 
tion, like the federal court prohibition, should not be considered as an absolute but, instead, as an expression of strict comity to be weighed against the demands of equity in the individual case.

\section{B. The State Court Prohibition and Traditional Grounds for Anti-Suit Injunctions}

Applying the traditional equity bases underlying anti-suit injunctions to the state court prohibition, it seems that state power to enjoin the prosecution of federal court proceedings generally should exist where the converse power exists in the federal courts.

1. Relitigation. In the relitigation area, in particular, state injunctive power seems desirable. Those considerations of equity and the need to protect the court's dignity and judgments which appear in the state-state and federal-state areas are equally important here.163 However, the Donovan case specifically struck down the state's power to issue such an injunction, although it affords one of the clearest examples of a situation where such power is desirable and necessary. ${ }^{164}$ The plaintiffs had had their day in court, and the controversy was finally adjudicated by a clearly competent tribunal. To permit these plaintiffs to re-open this case in a federal court would be to countenance not only an attempt to evade the prior state court judgment, and impose needless expenses and hardship upon the already victorious city, but would also effectively delay any construction on the municipal improvements, leading to a clear inference of a purpose to vex and harass. ${ }^{165}$ The equitable con-

No. 82. In defense of the proposed concurrency, he wrote that the "national and state systems are to be regarded as ONE WHOLE. The courts of the latter will of course be natural auxiliaries to execution of the laws of the union .... I hold that the state courts will be divested of no part of their primitive jurisdiction ... that in every case in which they were not expressly excluded by the future acts of the national legislature, they will of course take cognizance of the causes to which those acts may give birth." THE FEDERALIST No. 82, at 555-56 (Cooke ed. 1961).

163 Moore, Commentary on the U.S. Judiclal Code q 0.03, at 417 (1949).

164 The author of a recent article on the Donovan case does not agree that an injunction was necessary, although he criticizes the Court's broad denial of state injunctive power. According to his view, the City of Dallas had remedies other than an injunction equally available to it, in the form of a plea for a stay, or res judicata, in the federal court. See Arnold, State Power to Enjoin Federal Proceedings, 51 VA. L. Rev. 59 (1965). If it is true that under Texas law the bonds could not issue in either case, delaying any airport construction during appeals from either court or decision, then this interpretation has merit. Even granting this fact, however, there is still delay that can be created depending on who is appealing and who is the plaintiff, which might have a bearing on the course chosen by the city in Donovan. Moreover, the injunction obtained was a far more final remedy than dismissal in a federal court since it barred all future efforts to contest this issue, and provided a means for prompt and effective enforcement of the bar.

165 An additional fact in these cases was that under Texas law (Vernon's Tex. Grv. STAT., art. 1269j-5, $\$ 3$ (1963)) as long as litigation was pending in which the 
siderations in such a case would seem far to outweigh the possible dangers of interference, and state and federal courts in this case should be on equal terms with respect to the anti-suit injunction.

2. Fraud or Collusion. In the fraud or collusion area, it would seem to follow that where federal courts may enjoin the enforcement of state court judgments which have been obtained through fraud, the state courts should be able to do the same when faced with federal judgments similarly obtained. Furthermore, state courts are not constrained by the artificial distinction between completed and pending actions that exists with regard to federal injunctive power because of the term "proceedings" in section 2283, and should be able to enjoin pending federal proceedings upon a showing of irreparable harm resulting from fraud in that suit. ${ }^{166}$ Where the state court otherwise has jurisdiction over the parties and subject matter of the federal suit, the injunction does not frustrate national interests and the interference engendered should be measured against the equitable factors underlying the injunction.

3. Public Policy. As a general proposition, state courts should not be able to enjoin proceedings before a federal court for reasons of "public policy." For although the federal court has such power in certain situations, ${ }^{167}$ notions of reciprocity are not persuasive here. In most cases in which the federal injunctive power is so justified, overriding national interests are involved, and the supremacy clause is raised. In the nature of things, there are no state equivalents to the "Act of Congress," removal or exclusive jurisdiction bases for such injunctions.

Nevertheless, cases can be posited in which a federal court is clearly overstepping its jurisdiction and thus thwarting strong interests of the state, with harm resulting both to the state in its sovereign capacity and

validity of a proposed bond issue was in any manner questioned, the Texas attorney general could not authorize their sale, and thus any construction on the runway was effectively stayed. It is significant in this regard that the complainants, when in the federal court, no longer asked for a temporary injunction as in the state suit, but only for a permanent injunction. The former goal was achieved by the mere institution of the suit. The Texas Supreme Court, noting this fact, stated that "there is indication in the history of this matter that it has reached the point of vexatious and harassing litigation." City of Dallas v. Dixon, 365 S.W.2d 919, 927 (Tex. Sup. Ct. 1963).

166 See 7 Moore, Federal Practice If 60.40, at 648-52 (2d ed. 1955). This power, of course, must be limited to situations where concurrent state and federal jurisdiction exists, and not where the federal courts possess "exclusive jurisdiction." See also Simon v. Southern Ry., 236 U.S. 115 (1915). See generally 7 Moore, Federal Practice II $60.24,60.36,60.37$, at $245-57,601-35$ (2d ed. 1955).

167 E.g., under the "Act of Congress" exception in 28 U.S.C. $\$ 2283$ (1958), where the United States brings the suit, where an unconstitutional statute is involved, or where the exclusive jurisdiction of the federal courts is threatened. 
to certain of its citizens. In State $v$. Frost ${ }^{168}$ for example, the State of Wisconsin sought a state court injunction to prevent a receiver appointed by a federal court from dismantling and totally destroying a Wisconsin railroad pursuant to a mortgage foreclosure in the federal court. The Wisconsin court did not rule on the issue of the injunction directly, instead permitting removal to the federal court. ${ }^{169}$ Previously, however, the court did grant a temporary injunction pending full consideration of the questions (1) whether the state may prevent destruction of a roadbed constructed under a state-authorized franchise and over which the state had control in its sovereign capacity, and (2) whether "the right of the public to the continued existence of such highway is fundamental and superior to all rights of the corporation, either to exercise itself, or to pledge, mortgage, or convey to others, so that a physical destruction of that highway is a wrong against the public, which the state may prevent." 170

Similarly, in a diversity action where a federal court is applying state law pursuant to the Erie doctrine, there is no valid reason for preventing a court of another state from enjoining to prevent evasion of its own laws, subject to the restrictions that exist between state courts in such situations. ${ }^{171}$

4. Multiplicity of Actions and Concurrency. As in the state-state and federal-state areas, state injunctions should not, as a rule, issue to bar federal suits for purposes of avoiding a multiplicity of actions on the same cause. However, the state court here is not bound by the provisions of a statute and situations may arise where the equitable needs outweigh the evils of interference. In University of Texas v. Morris, ${ }^{172}$ for example, an expelled student had brought a number of suits in different courts against the University for his alleged wrongful discharge. Indeed, the former student had threatened to continue suing "until death do we part" in an effort to force the University to settle.173 On the defendant's motion, the Texas suits were consolidated and the plaintiff was enjoined from prosecuting an additional suit in a federal court in New Mexico. The Supreme Court of Texas affirmed the issuance of

168113 Wis. 623, 89 N.W. 915 (1902).

169 The power of the state court to determine the elements necessary for federal jurisdiction and to authorize removal was not considered by the court. However, all the elements necessary for removal were thoroughly discussed. Still, the final decision as to removal would have to be made by the federal court. There is no record of the subsequent disposition or history of this case.

170113 Wis. at 639,89 N.W. at 917.

171 See Royal League v. Kavanagh, 233 Ill. 175, 84 N.E. 178 (1908).

172162 Tex. 60, 344 S.W.2d 426, cert. denied, 366 U.S. 973 (1961).

173 This information was contained in a letter written by the plaintiff to the attorneys for the defendants. 162 Tex. at 63, 344 S.W.2d at 429 . 
the injunction, stating that "a district court having jurisdiction of the parties and the subject matter may enjoin a party from prosecuting a cause of action in another court when such relief is necessary to prevent a multiplicity of suits, avoid vexatious litigation, or prohibit the use of the judicial processes for purposes of harassment."174 The court made no mention of the state court prohibition, but it would seem that the bar should have made no difference. When the jurisdiction of any court, whether federal or state, is invoked for the purposes of harassment or oppression, the goals of non-interference should yield to the equitable justifications for the anti-suit injunction.

\section{CONCLUSION}

Writing on the federal abstention doctrine, Professor Kurland has stated: "It seems to me that if we can only rid ourselves of the notion of contest between the state and federal courts, as well as among state courts; if we can substitute therefor a concept of co-operative federalism, we can come closer to the constitutional ideal."175 This notion is also applicable to the anti-suit injunction. The chief objection to the injunction has been that it engenders friction between courts, resulting at times in a virtual power struggle, which aggravates rather than settles conflicts. ${ }^{178}$

Between federal and state courts, these problems are especially acute, and the "independence" of the two judicial systems cannot be lightly disregarded. However, this comment has suggested that in certain areas the anti-suit injunction may be employed without seriously affecting the desired independence. Indeed, it has been suggested that the elimination of the current double standard may serve to enhance, rather than diminish, progress toward the goal of a "co-operative federalism." Nevertheless, once these propositions are accepted, further problems remain.

Because the anti-suit injunction is operative only against the party enjoined, and not the foreign court, there is always the possibility that the injunction will be ignored and that the foreign court will proceed to hear the suit "enjoined." Since decisions have generally upheld the proposition that a court is not bound to give full faith and credit to

174 I62 Tex. at 62,344 S.W.2d at 428 . The Texas court regarded the number of suits instituted and the time over which these had been brought as important in establishing the motive to vex and harass, noting that "had Morris instituted but two suits, one in Texas and a later one in New Mexico, there undoubtedly would have existed a lack of equity." Ibid.

175 Kurland, Toward a Co-operative Judicial Federalism: The Federal Court Abstention Doctrine, 24 F.R.D. 481, 492 (1960).

176 Id. at 489. 
the injunction, ${ }^{177}$ the equitable reasons underlying the injunction may be thwarted, with a resulting increase in the tension between the respective courts. In many cases, the threat of contempt citations, or further injunctions by the enjoining court, will serve to deter the enjoined party and thus alleviate these dangers. ${ }^{178} \mathrm{However}$, in some cases real conflict arises if the second court decides to enjoin the party with the injunction from proceeding elsewhere 179 or to counter-enjoin the enforcement of the injunction.180 In such cases, the dignity of the respective courts is damaged, all notions of comity and mutual respect upset, and, most of all, innocent parties are placed in painful dilemmas.

Fortunately, these extremes have seldom resulted.181 Ideally, the second court should respect the anti-suit injunction of the first and dismiss or stay the action before it, if only for reasons of comity. ${ }^{182}$ Since the injunc-

177 Wells v. Wells, 230 Ala. 430, 161 So. 794 (1935); James v. Grand Trunk West. R.R., 14 Ill. 2d 356, 152 N.E.2d 858 (1958); Lancaster v. Dunn, 153 La. 15, 95 So. 385 (1922); State ex rel. Bossung v. District Court, 140 Minn. 494, 168 N.W. 589 (1918). See generally Comment, 6 Sr. Louss U.L.J. 552 (1961); Comment, 26 U. CHI. L. REV. 633 (1959).

178 Note, 27 Iown L. REv. 76, 80 (1941).

170 See Peck v. Jenness, 48 U.S. (7 How.) 612, 625 (1849), where the Court, stating the rule that the court first taking jurisdiction can settle all matters to the exclusion of all other courts, noted "for if one [court] may enjoin, the other may retort by injunction, and thus the parties be without remedy; being liable to a process for contempt in one, if they dare to proceed in the other." This case involved a proceeding in rem, however. The actual problem of injunction-injunction has never arisen in practice, and probably never will, due to the residency requirements for an injunction to be issued and considerations of comity.

180 Chicago, M. \& St. Paul Ry. v. Schendel, 292 Fed. 326 (8th Gir. 1923); James v. Grand Trunk West. R.R., 14 IIl. 2d 356, I52 N.E.2d 858 (1958); Peterson v. Chicago, B. \& Q. Ry., 187 Minn. 228, 244 N.W. 823 (1932). The James case furnishes an excellent example of the extremes to which a court may go. The Illinois Supreme Court held that the Illinois trial court should issue a counter-injunction to bar the enforcement of an injunction obtained by the Michigan defendant in Michigan to bar the Illinois suit. All parties were from Michigan, the cause had arisen there, and suit was brought under the Michigan wrongful death act, which contained "venue" provisions requiring that suit be brought in a county through which the tracks of the railroad ran, here in Michigan. The court stated: "However, this court need not, and will not, countenance having its right to try cases, of which it has proper jurisdiction, determined by the courts of other States, through their injunctive process. We are not only free to disregard such out-of-State injunctions, and to adjudicate the merits of the pending action, but we can protect our jurisdiction from such usurpation by the issuance of a counter-injunction restraining the enforcement of the out-of-State injunction." 14 Ill. 2d at 372, 152 N.E.2d at 867. There was a vigorous dissent on this latter point by Justice Schaefer. Id. at 374-75, 152 N.E.2d at 868

I81 Southern Ry. v. Painter, 314 U.S. 155 (1941) (counter-injunction denied); Bryant v. Atlantic Coast R.R., 92 F.2d 569 (2d Gir. 1937) (L. Hand, J., counter-injunction denied); State ex rel. New York, C. \& St. L.R.R. v. Nortoni, 391 Mo. 764, 55 S.W.2d 272 (1932) (counter-injunction denied).

182 See Blanchard v. Commonwealth Oil Co., 294 F.2d 834 (5th Cir. 1961); Allen v. Chicago G.W.R.R., 239 Ill. App. 38, 43 (1925). 
tion is an extreme remedy, and one that courts employ with caution and only to prevent immediate and irreparable harm, the second court should defer to the judgment of the first.

Within the bounds of strict comity between federal and state courts, the limited use of the anti-suit injunction seems desirable. It is as important in the federal-state area as it is in the state-state area that courts be able to protect their jurisdiction, their judgments, and parties over whom they are equitably responsible. Where the equitable or policy bases for an injunction outweigh the dangers of "interference," such injunctions should issue, regardless of whether the suit enjoined is "federal" or "state." The goal of "co-operative federalism" can only be achieved through equality and mutual respect, neither of which is furthered by the present double standard. 